\title{
Aspek Hukum Dalam Pelestarian Sumber Daya Genetik Laut: Kebutuhan dan Tantangan
}

\author{
Isna Fatimah ${ }^{1}$
}

\begin{abstract}
Abstrak
Pelestarian sumber daya genetik laut (SDG laut) merupakan kegiatan yang meliputi upaya-upaya pemanfaatan dan pelindungan SDG laut sebagai investasi potensial dalam mewujudkan pembangunan berkelanjutan. Sebagai negara yang dianugerahi kemewahan wilayah laut kepulauan, seharusnya perhatian terhadap SDG laut sudah mengemuka. Sayangnya, Indonesia belum mempunyai kerangka hukum yang komprehensif dalam mengatur pelestarian SDG laut. Tulisan ini bermaksud memberikan gambaran tentang kebutuhan dan tantangan Indonesia dalam mengatur pelestarian SDG laut. Fokus penulisan dibatasi pada aspek hukum dalam manajemen pemanfaatan dan pelindungan SDG laut. Metode penelitian yang digunakan adalah pendekatan normatif dengan menelaah perjanjian internasional yang telah diratifikasi Indonesia, berkenaan dengan hukum laut dankeanekaragaman hayati, serta beberapa peraturan nasional lain yang terkait. Adapun berbagai teori dan informasi pendukung diperoleh melalui data dan bahan hukum sekunder. Hasil penelitian menunjukkan bahwa kebutuhan sekaligus menjadi tantangan dalam membangun kerangka hukum pelestarian SDG laut meliputi: (1) pembuatan kerangka kebijakan integratif tentang penguasaan negara dan hak masyarakat atas pemanfaatan SDG laut; (2) penguatan koordinasi antar instansi yang mengemban fungsi terkait pelestarian SDG laut; dan (3) penguatan dan harmonisasi berbagai peraturan perundang-undangan terkait pelestarian SDG laut.
\end{abstract}

Kata Kunci: pelestarian, sumber daya genetik laut, keanekaragaman hayati, laut, pembangunan berkelanjutan.

\section{Abstract}

The scope of preserving marine genetic resources (MGRs) shall involve the act of utilization

1 Isna Fatimah lulus dari Fakultas Hukum Universitas Indonesia pada tahun 2013, dan sekarang merupakan Asisten Peneliti di Indonesian Center for Environmental Law, terutama dalam bidang konservasi, perlindungan dan tata kelola lingkungan hidup yang baik, serta kelautan. 
and protection towards sowing potential benefits to reach sustainable development. Privileged by its archipelagic form, Indonesia should have been in the forefront in valuing the importance of MGRs. Unfortunately, comprehensive regulations on the preservation of MGRs are not yet exist in Indonesia. This article aims to give description on the needs and challenges to regulate preservation of MGRs in Indonesia. This article is focusing on legal aspect in the management of utilization and protection of MGRs. Method conducted for this research is normative approach by analyzing ratified international agreements regarding law of the sea and biodiversity and other relevant national regulations. Meanwhile, supporting theories and information are obtained through secondary data and literature of laws. The research shows that needs as well as challenges in designing legal framework on MGRs requires: (1) creating integrative policy on State's sovereignty and people's right over MGRs utilization; (2) strengtening coordination among institutions; and (3) strengthening and harmonizing regulations related to MGRs.

Keywords: preservation, marine genetic resources, biodiversity, law of the sea, sustainable development.

\section{Pendahuluan}

Diskursus mengenai pelestarian sumber daya genetik (SDG) laut hingga saat ini masih terus berkembang dalam konstelasi isu lingkungan hidup dan sumber daya alam (SDA). Dalam perkembangannya, terdapat dua instrumen hukum internasional utama yang menjadi landasan, yaitu: the United Nations Convention on the Law of the Sea 1982 (UNCLOS) ${ }^{2}$ dan the Convention on Biological Diversity 1992 (CBD). ${ }^{3}$ Adapun perkembangan ide pengaturan SDG laut dipengaruhi oleh cita-cita pembangunan berkelanjutan (sustainable development) ${ }^{4}$ yang erat kaitannya dengan pemenuhan keadilan lingkungan (environmental justice). ${ }^{5}$ Tarik menarik kepentingan

2 United Nations, United Nations Convention on the Law of the Sea, Montego Bay, 10 December 1982 (UNCLOS 1982).

3 United Nations, Convention on Biological Diversity, Rio de Jeneiro, 5 June 1992.

4 Sustainable development menurut World Commission on Environment and Development adalah pembangunan yang mampu memenuhi kebutuhan generasi sekarang tanpa mengganggu kemampuan generasi yang akan datang untuk memenuhi kebutuhanya. Komponen pembangunan berkelanjutan terdiri atas prinsip integrasi, prinsip pemanfaatan berkelanjutan, prinsip keadilan intra generasi, dan prinsip keadilan antar generasi. Lihat: Philippe Sands, Principles of International Environmental Law, $2^{\text {nd }}$ Ed., (Cambridge University Press: New York, 2003), hlm. 199.

5 Keadilan lingkungan merupakan salah satu komponen inti dari konsep pembangunan berkelanjutan. Konteks keadilan lingkungan dalam hal ini merujuk pada keadilan intra dan antar generasi. Kuehn membagi keadilan lingkungan dalam empat kategori: keadilan 
dan disparitas penguasaan teknologi antara negara utara ${ }^{6}$ dengan negara selatan ${ }^{7}$ menjadikan isu ini terus meluas dan berjalinan dengan ragam aspek. Di sisi lain, pelestarian SDG laut tidak bisa dilakukan tanpa kerja sama di tingkat global. ${ }^{8}$

Indonesia termasuk kelompok negara selatan yang harus melakukan kerja keras untuk bisa melaksanakan kewajiban-kewajiban hukumnya sebagai anggota (contracting party) UNCLOS dan CBD, termasuk kewajiban dalam pelestarian SDG laut. ${ }^{9}$ Salah satu sebab banyaknya komitmen Indonesia terkait SDG laut yang belum dapat dilaksanakan adalah ketidaktersediaan kerangka hukum yang memadai. Namun lebih dari itu, yang lebih penting adalah bagaimana menggunakan UNCLOS dan CBD untuk pemenuhan kebutuhan rakyat Indonesia dan penjaminan hak-hak masyarakat atas SDG laut sebagai bagian dari sumber daya alam hayati (SDA hayati). Pemenuhan kebutuhan rakyat tersebut mensyaratkan dilakukannya pelestarian SDG laut yang berkelanjutan, meliputi upaya-upaya pemanfaatan dan pelindungan.

SDG dalam konteks keanekaragaman hayati laut adalah setiap unsur makhluk hidup (biota baik fauna maupun vegetasi) di laut dan pesisir yang membawa sifat hereditas. ${ }^{10}$ Keanekaragaman hayati dimaksud mencakup tingkat genetik, spesies dan ekosistem laut. ${ }^{11}$ SDG merupakan unsur yang melekat pada biotanya sehingga perlindungan terhadap ekosistem, spesies dan biota menjadi prasyarat

distributif, keadilan korektif, keadilan prosedural dan keadilan sosial. Lihat: Robert R. Kuehn, “A Taxonomy of Environmental Justice," Environmental Law Reporter Vol. 30 p. 10681, 2000, hlm. 10683-10684. Diakses dari Social Science Research Network: http://papers.ssrn.com/ sol3/papers.cfm?abstract id=628088 pada 5 Oktober 2015.

6 Istilah negara utara merujuk pada negara dengan kekuatan ilmu pengetahuan dan teknologi sehingga mempunyai kepentingan (interest) lebih, didukung kemampuan, untuk mengakses sumber daya genetik di berbagai wilayah dunia.

$7 \quad$ Istilah negara selatan merujuk pada negara penyedia sumber daya genetik (biasanya merupakan negara yang kaya akan keanekaragaman hayat) namun tidak mempunyai cukup ilmu pengetahuan dan teknologi.

8 Sands, op. cit., hlm. 3.

9 Indonesia meratifikasi UNCLOS 1982 melalui Undang-Undang Nomor 17 Tahun 1985 tentang Pengesahan United Nations Convention on the Law of the Sea 1985 (Konvensi Perserikatan Bangsa-Bangsa tentang Hukum Laut 1982). CBD diratifikasi melalui Undang-Undang No. 5 Tahun 1994 tentang Pengesahan United Nations Convention on Biological Diversity (Konvensi Perserikatan Bangsa-Bangsa Mengenai Keanekaragaman Hayati).

10 CBD Secretariat, Status and trends of, and threats to, deep seabed genetic resources beyond national jurisdiction, and identification of technical options for their conservation and sustainable use. UNEP/ CBD/SBSTTA/11/11. Par. 10, sebagaimana dikutip dalam Thomas Greiber (a), “Access and Benefit Sharing in Relation to Marine Genetic Resources from Areas Beyond National Jurisdiction: A Possible Way Forward, (Bonn: BN Federal Agency for Nature Conservation, 2011), hlm. 4.

11 Eyjolfur Gudmundsson, "Challenges of Marine Biodiversity," (Chicago: The University of Chicago Press, 1998), hlm 2 
upaya pelestarian SDG. ${ }^{12}$ Agar tidak ada potensi yang hilang atau mengalami erosi, tingkat keragaman SDG sebagai bagian dari keanekaragaman hayati ${ }^{13}$ perlu dijaga stabilitasnya. ${ }^{14}$ Stabilitas keragaman SDG diperlukan tidak hanya untuk menjaga kemampuan bertahan hidup dan adaptasi makhluk hidup, tetapi juga menjawab tantangan ketahanan pangan, kesehatan, ${ }^{15}$ berbagai industri penting dan ketahanan lingkungan terhadap perubahan iklim. ${ }^{16}$ Besarnya potensi tersebut mendorong animo pemanfaatan SDG terus meningkat seiring perkembangan teknologi dan bertambahnya kebutuhan manusia. SDG diyakini sebagai sumber daya yang mampu menopang kebutuhan masa depan serta menjadi prasyarat konservasi dalam agenda pembangunan berkelanjutan. ${ }^{17}$

Dalam kurun waktu 35 tahun terakhir, lautan mengalami perubahan signifikan disebabkan oleh aktivitas manusia. ${ }^{18}$ Pelindungan SDG laut-sebagai penentu

12 SDG merupakan komponen yang membentuk unit fungsional pewarisan sifat pada makhluk hidup dan memungkinkan terjadinya keragaman genetika/sejumlah variasi genetika pada suatu spesies atau populasi. Lihat: Annie Patricia, Kameri-Mbote, Philippe Cullet, "The Management of Genetic Resources: Developments In The 1997 Sessions of the Commission On Genetic Resources For Food and Agriculture," Colorado Journal of International Environmental Law and Policy, 1997, 78, sebagaimana dikutip oleh Efridani Lubis, "Penerapan Konsep Sovereign Right dan Hak Kekayaan Intelektual dalam Perspektif Perlindungan dan Pemanfaatan SDG Indonesia," (Disertasi: Universitas Indonesia, 2009), hlm. 45.

13 Istilah keanekaragaman hayati merupakan terjemahan dari 'biological diversity' yang menurut teks CBD diartikan: "... the variability among living organisms from all sources including, inter alia, terrestrial, marine and other aquatic ecosystems and the ecological complexes of which they are part: this includes diversity within species, between species and of ecosystems."

14 Maxted dan Guarino, Genetic erosion and genetic pollution of crop wild relatives, 2006, dalam B.V. Ford-Lloyd, S.R. Dias and E. Bettencourt, eds. Genetic Erosion and Pollution Assessment Methodologies. Proceedings of PGR Forum Workshop 5, Terceira Island, Autonomous Region of the Azores, Portugal, 8-11 September 2004, pp. 35-45. Published on behalf of the European Crop Wild Relative Diversity Assessment and Conservation Forum, by Bioversity International, Rome, Italy. 100 pp. Available at http://www.bioversityinternational.org/ fileadmin/bioversity/publications/pdfs/1171.pdf (accessed 11 January 2010). sebagaimana dikutip dalam Anthony H.D. Brown, Indicators of Genetic Diversity, Genetic Erosion and Genetic Vulnerability for Plant Genetic Resources for Food and Agriculture, (Rome, 2008), hlm. 13.

15 Menurut Arieta J.M., Arnaud-Haond, dan C.M. Duarte, jumlah pemanfaatan SDG laut yang telah dipatenkan (patented Marine Genetic Resources) paling banyak dimanfaatkan untuk bidang kesehatan manusia. Lihat: Arieta J.M., Arnaud-Haond, dan C.M. Duarte, "What Lies Underneath: conserving the Oceans' Genetic Resources," dalam presentasi berjudul "Marine Biodiversity and Gene Patents: Balancing the Preservation of Marine Genetic Resources (MGR) and the Equitable Generation of Benefits for Society", (Mediterranean Institute for Advanced Studies [IMEDEA], Spanish National Research Council [CSIC], 2010), hlm. 7.

16 Lihat diantaranya: FAO, Coping with climate change - the roles of genetic resources for food and agriculture, Rome, 2015); Lyle Glowka et. al (c), A Guide to the Convention on Biological Diversity, (International Union for Conservation of Nature and Natual Law (IUCN), 1996).

17 Thomas Greiber, et. al., "An Explanatory Guide to the Nagoya Protocol on Access and Benefitsharing," (IUCN, Gland, Switzerland, 2012), hlm. 4.

18 S. Arico, C. Salpin, Bioprospecting of Genetic Resources in the Deep Seabed: Scientific, Legal and Policy Aspects, (United Nations University-Institute of Advanced Studies, 2005), hlm. 8 sebagaimana dikutip Greiber (a), op. cit., hlm. 1. 
kemampuan bertahan hidup dan adaptasi SDA hayati di dalamnya - oleh karenanya menjadi sangat krusial. ${ }^{19}$ Adapun aktivitas yang pertama kali menstimulus penelitian SDG laut adalah penemuan hydrothermal vents ${ }^{20}$ dan mikroba unik yang hidup di dalamnya. ${ }^{21}$ Penemuan ini menghasilkan kesimpulan bahwa organisme yang ada di kedalaman laut merupakan materi yang sangat potensial untuk perkembangan ilmu pengetahuan, teknologi dan industri. ${ }^{22}$

Indonesia, sebagai salah satu negara megabiodiversity ${ }^{23}$ yang $70 \%$ wilayahnya berupa lautan selayaknya menaruh perhatian besar dalam pelestarian potensi SDA hayati laut. Dengan luas laut (termasuk zona ekonomi eksklusif/ZEE) sekitar 5,8 juta kilometer, ${ }^{24}$ potensi SDA hayati laut Indonesia untuk pemanfaatan SDG sangat menjanjikan. Misalnya saja keberadaan hydrothermal vents ${ }^{25}$ berstatus aktif yang

19 Meskipun kemampuan SDA hayati laut untuk memulihkan diri jauh lebih baik dibandingkan dengan SDA hayati di daratan, besarnya aktivitas di laut saat ini sudah di luar kewajaran dan mengancam ketahanan keanekaragaman hayati laut. Aktivitas dimaksud mencakup eksploitasi sumber daya laut terutama yang dilakukan secara berlebihan atau menggunakan cara-cara desktruktif, pembuangan limbah (dumping), pencemaran, polusi, transportasi dan instalasi bangunan di laut. Lihat: Arico, Ibid; Gudmundsson, op. cit., hlm 3.

20 Hydrothermal vent adalah palung di dasar laut yang mengeluarkan air panas geothermal. Dengan kondisinya yang unik, di mana tidak ada sama sekali sinar matahari yang masuk, hydrothermal vents diketahui kaya akan SDA hayati yang mempunyai kemampuan survival dan resilience yang tinggi dalam genetiknya sehingga sangat potensial untuk dikaji. Ada pula hipotesis yang dipercaya oleh para peneliti sains bahwa hydrothermal vents menggambarkan asal usul bermulanya kehidupan di bumi (origin oflife). Baross dan Hoffman mengungkapkan teori bahwa kehidupan di laut berasal dari lingkungan yang sangat mirip dengan hydrothermal vents. Lihat: J.A. Baross dan S.E. Hoffman, "Submarine Hydrothermal Vents and Associated Gradient environments as sites for the origin and evolution of life," (2 Naval Research Reviews 2, 6, 1986) sebagaimana dikutip David Kenneth Leary, International Law and the Genetic Resources of the Deep Sea, (Koninklijke Brill NV, Leiden, The Netherlands, 2007), hlm. 20.

21 Lihat: (1) Gerd Winter dan Evanson Chenge Kamau, Genetic Resources, Traditional Knowledge and the Law: Solutions for Access and Benefit Sharing, (London: Earthscan, 2009), hlm. 58. (2) Lyle Glowka (a), "Genetic resources, marine scientific research and the international seabed Area," Vol 8 Issue 1 1999, (Blackwell Publishers, Ltd: Oxford, 1999).

22 Penyebutan kata potensial dimaksudkan bahwa SDG laut merupakan bagian dari SDA yang dinilai mempunyai potensi manfaat yang belum diketahui manusia. Ini merupakan keunikan dari ide tentang pelindungan SDG yang dilakukan terhadap SDG yang sudah diketahui manfaatnya maupun yang belum. SDG yang belum diketahui manfaatnya dianggap mempunyai potensi kemanfaatan. Lihat: Kamau, Ibid, hlm. 58 mengutip R.J. McLaughlin, "Foreign acess to shared marine genetic materials: Management options for a quasi-fugacious reseource," Ocean Development and International Law, vol 34, pp 297-348.

23 Megabiodiversity merupakan istilah yang merujuk pada negara-negara dengan tingkat keanekaragaman hayati tertinggi di dunia.

24 Kementerian Lingkungan Hidup, “Deskripsi Peta Ekoregion Laut Indonesia," (Deputi Tata Lingkungan, Kementerian Lingkungan Hidup, Jakarta, 2013), hlm. 8.

25 Hydrothermal vents diyakini menjadi tempat hidup organisme yang mempunyai kemampuan bertahan hidup (resilience) paling tinggi sehingga menarik untuk diteliti. Lihat: Leary, loc. cit. 
terletak di Kepulauan Sangihe, Sulawesi Utara dan Kepulauan Banda, Maluku. ${ }^{26}$ Belum lagi kekayaan terumbu karang dan SDA hayati Indonesia di area Coral Triangle yang menjadi salah satu tumpuan ketahanan ekosistem laut, sumber pangan dan ragam manfaat lain bagi manusia di seluruh dunia. ${ }^{27}$ Secara historis, Indonesia juga selalu menjadi bagian penting dari sejarah hukum laut internasional ${ }^{28}$ serta selalu muncul sebagai test case bagi dokumen-dokumen internasional terkait SDA hayati. ${ }^{29}$ Terlihat bahwa pemanfaatan SDA hayati Indonesia, termasuk juga pemanfaatan SDG lautnya, telah mencuri perhatian dunia sejak lama.

Ragam hasil penelitian SDG laut Indonesia telah mengembara di berbagai publikasi ilmiah tanpa tercatat dengan baik dalam basis data pemerintah. ${ }^{30}$ Penelitian-penelitian SDG laut banyak yang masuk dalam domain publik atau diprivatisasi untuk kepentingan ekonomi tanpa ada pembagian keuntungan yang adil dan berimbang untuk Indonesia. Di samping itu, banyak penelitian yang bisa memberi petunjuk tentang cara melakukan konservasi di laut namun tidak dimanfaatkan dengan baik oleh Indonesia. Penelitian-penelitian semacam ini hanya menjadi publikasi ilmiah di berbagai media publikasi asing. ${ }^{31}$ Sayangnya Indonesia belum mempunyai mekanisme akses dan pembagian keuntungan yang mumpuni

26 Data diperoleh dari http://www.interridge.org/irvents/ventfields list all?page=1 , diakses pada 26 September 2015 pukul 13.38. Data ini terakhir kali diperbarui pada 29 Juni 2011.

27 Coral Triangle Initiative, "About CTI-CFF", diakses dari http://www.coraltriangleinitiative. org/about-us pada 5 Desember 2015 pukul 10:43.

28 United Nations, "The United Nations Convention on the Law of the Sea (A historical perspective)," dari http://www.un.org/depts/los/convention_agreements/convention_ historical perspective.htm diakses pada 5 Oktober 2015 pukul 15.00.

29 IUCN, op. cit.

30 Sebagai gambaran, sampai tahun 2.000 ada sekitar 2.700 hasil penelitian tentang spons yang dipublikasikan di seluruh dunia, di mana 850 jenis spons diantaranya merupakan endemik Indonesia. Lihat: Ekowati Chasanah, "Marine Biodiscovery Research in Indonesia: Challenges and Rewards," (Journal of Coastal Development Vol. 12 No. 1:1-12, ISSN: 1410-5217, 27 August 2008). Mengutip NJ. De Voogd, "Indonesian Sponges: Biodiversity and mariculture potential," (PhD Thesis, University of Amsterdam, the Netherlands, 2005) dan N. Fusateni, “Drugs from the Sea," (Karger, 2000), hlm. 158.

31 Sebagai contoh adalah penemuan tentang kandungan omega-3 berkualitas tinggi pada Sardinella lemuru di Selat Lombok yang dipublikasikan di United State's National Center for Biotechnology Information. Dalam publikasi ini muncul petunjuk tentang penelitian lanjutan yang perlu dilakukan untuk mengetahui cara melindungi spesies tersebut. Di sisi lain, publikasi ini bisa mengundang minat industri farmasi mengakses Sardinella lemuru untuk dikembangkan menjadi obat-obatan atau vitamin, mengingat omega-3 merupakan lemak esensial yang berkhasiat mencegah penyakit jantung dan struk, mengendalikan penyakit lupus dan pertumbuhan kanker. Lihat: (1) NCBI, http://www.ncbi.nlm.nih.gov/ pubmed/23275733, diakses pada 30 November 2015 pukul 21.09. (2) Harvard edu, http:// www.hsph.harvard.edu/nutritionsource/omega-3-fats/, diakses pada 30 November 2015 pukul 21:30. 
sehingga praktik biopiracy ${ }^{32}$ bisa terjadi tanpa terawasi. Selain itu, belum ada pula perangkat yang memadai untuk menindaklanjuti setiap hasil penelitian demi kepentingan konservasi.

Berdasarkan uraian tersebut, jelas bahwa pelestarian SDG laut memegang peranan penting bagi keberlanjutan keanekaragaman hayati laut. Pelestarian yang dimaksud merujuk pada modern conservation thinking yang diperkenalkan oleh CBD. ${ }^{33}$ Pelestarian SDG laut mencirikan dilakukannya konservasi modern terhadap keanekaragaman hayati laut. Istilah yang lebih merefleksikan maksud conservation dalam CBD adalah "pelestarian." 34

Pada skala global, CBD telah menjadi rujukan umum untuk konservasi keanekaragaman hayati. Dalam dokumen "A Guide to CBD", kegiatan conservation umumnya diterjemahkan dengan istilah "konservasi" - yang diatur dalam CBD berlandaskan keadilan menurut pemikiran konservasi modern. ${ }^{35}$ Maksudnya adalah, konservasi tidak hanya dilakukan untuk melindungi nilai intrinsik dan keaslian keanekaragaman hayati tanpa intervensi tetapi juga bagaimana keanekaragaman hayati tersebut dapat dimanfaatkan sepanjang menurut cara-cara yang berkelanjutan. ${ }^{36}$ Di era sekarang, pemanfaatan berkelanjutan bahkan menjadi syarat konservasi atas komponen tertentu dari keanekaragaman hayati yang membutuhkan perlakukan khusus, di mana SDG laut termasuk di dalamnya. ${ }^{37}$

32 Biopiracy adalah istilah yang tidak resmi namun umum digunakan untuk menjelaskan suatu tindakan mengambil alih pengetahuan atas suatu SDG dari pihak yang lebih dahulu mempunyai pengetahuan tersebut dan memperoleh keuntungan darinya tanpa memberi kompensasi pada pemilik pengetahuan asal. Biopiracy diartikan sebagai pengambilalihan atau komersialisasi atas SDG dan pengetahuan yang terasosiasi dengannya yang dilakukan secara ilegal atau bertentangan dengan prinsip pembagian keuntungan. Lihat: Miguel N Alexiades dan Sarah A Laird, "Laying the Foundation: Equitable Biodiversity Research Relationships" dalam Sarah A Laird (ed), Biodiversity and Traditional Knowledge: Equitable Partnerships in Practice, (Earthscan, 2002), sebagaimana dikutip Achmad Gusman Catur Siswandi, "Marine Bioprospecting: International Law, Indonesia and Sustainable Development," (Thesis submitted for the degree of Doctor of Philosophy of The Australian National University, January 2013).

33 Lyle Glowka et. al (b), A Guide to the Convention on Biological Diversity, (International Union for Conservation of Nature and Natual Law (IUCN), 1996), hlm. 4.

34 Menurut Kamus Besar Bahasa Indonesia, pelestarian adalah: “..pengelolaan sumber daya alam yang menjamin pemanfaatannya secara bijaksana dan menjamin kesinambungan persediaannya dengan tetap memelihara dan meningkatkan kualitas nilai dan keanekaragamannya." Lihat: Kbbi.web.id/lestari, diakses pada 28 November 2015 pukul 11.20 .

35 Ibid.

36 Ibid, dengan penambahan oleh penulis.

37 "On the whole, in spite of its haziness regarding the term conservation, the Convention does justice to modern conservation thinking. Not only does it consistently recognize that sustainable use of living resources and the ecosystems of which they are a part is a prerequisite for biodiversity conservation, it 
Pelestarian SDG laut merupakan satu komponen dari pelestarian lingkungan hidup yang sebenarnya merupakan kepentingan nasional yang mempunyai implikasi global. Sebabnya adalah, SDG laut menyimpan begitu banyak potensi karena keunikan dan keragamannya yang lebih kaya daripada SDG daratan. ${ }^{38}$ Akibatnya, negara-negara yang mempunyai kekuatan teknologi berlomba-lomba untuk melakukan penelitian dan memanfaatkan SDG laut.

Artikel ini selanjutnya akan menguraikan secara deskriptif aspek hukum dalam manajemen pelestarian SDG laut dari sisi pengaturannya-tidak mencakup penerapan ataupun aspek penegakan hukum. Adapun pisau analisis yang digunakan untuk mengulik tantangan ke depan yang dihadapi Indonesia dalam membangun kerangka hukum untuk pelestarian SDG laut adalah UNCLOS dan CBD dilihat dari perspektif pembangunan berkelanjutan. Struktur pembahasan setelah bagian pendahuluan ini secara runut diikuti penjelasan mengenai pisau analisis, konsep penguasaan negara atas SDG laut, aspek hukum dalam pemanfaatan SDG laut, aspek hukum dalam pelindungan SDG laut dan kesimpulan.

\section{Pisau Analisis}

Pengaturan pada tingkat undang-undang yang paling dekat relevansinya dengan pelestarian SDG laut di Indonesia hingga saat ini adalah Undang-Undang tentang Ratifikasi UNCLOS dan CBD. ${ }^{39}$ Walaupun tidak cukup operasional, kedua instrumen tersebut menawarkan konsep pemanfaatan dan pelindungan SDA hayati secara berkesinambungan. Sementara beberapa undang-undang lain terkait sumber daya laut yang sudah ada cenderung parsial dan belum komprehensif melihat dari skala besar sampai mendetil aspek-aspek hukum yang dibutuhkan dalam pelestarian SDG laut. ${ }^{40}$ Sehingga pemilihan UNCLOS dan CBD sebagai pisau

also acknowledges the need for certain components to be given special care and treatment. Thus, the provisions on conservation and sustainable use reflect the full spectrum of measures needed to achieve the overall goal of the Convention." Lihat: Ibid.

38 Hipotesis utama dari keunggulan potensi SDG laut adalah diyakini mempunyai kemampuan bertahan hidup dan ketahanan yang lebih kuat dibandingkan SDG daratan. Lihat: (1) C.S. Holling, D.W. Schindler, B.W. Walker dan J. Roughgarten, Biodiversity in the Functioning of Ecosystems: An Ecological Synthesis, dalam Biodiversity Loss: Economic and Ecological Issues, C. Perrings, K. Maler, C. Folk, C. Holling dan B-O Jansson, (Cambridge: Cambridge Univeristy Press, 1995), sebagaimana dikutip Eyjolfur Gudmudsson, op. cit., hlm. 76. (2) Gudmundsson, ibid., hlm. 76.

39 Lihat catatan kaki 8.

40 Pendapat ini akan dikonfirmasi dalam pembahasan tentang aspek hukum pemanfaatan dan pelindungan SDG laut (bagian 4 dan 5). 
analisis bisa membantu menyisir permasalahan dengan lebih lengkap.

Pada tahun 1980, International Union for Conservation of Nature (IUCN) meluncurkan Strategi Konservasi Dunia (World Conservation Strategy/WCS). Strategi ini disusun sebagai tanggapan atas kekhawatiran yang timbul dari laju eksploitasi tanpa mengindahkan keterbatasan SDA dan kebutuhan generasi mendatang. ${ }^{41}$

Secara otomatis WCS mempengaruhi perkembangan negosiasi transnasional tentang hukum laut, hingga UNCLOS, yang lahir pada 1982, telah memuat semangat konservasi bagi living resources. ${ }^{42}$ Meskipun UNCLOS pada akhirnya tidak mengadopsi pengaturan spesifik tentang SDG laut, tetapi di dalamnya telah memuat pengaturan tentang pelaksanaan kedaulatan negara atas living resources di laut dan hak melakukan penelitian ilmiah kelautan (marine scientific research).${ }^{43} \mathrm{Di}$ samping itu, UNCLOS mengatur pelindungan dan preservasi lingkungan laut. ${ }^{44}$

Materi dalam WCS yang diusung IUCN kemudian menjadi pelopor lahirnya CBD. Tujuan yang hendak dicapai oleh CBD adalah untuk konservasi keanekaragaman hayati, pemanfaatan komponen keanekaragaman hayati secara berkelanjutan, serta pembagian keuntungan yang adil dan berimbang dari

41 IUCN, World Conservation Strategy, (IUCN-UNEP-WWF, 1980). Ide dalam WCS berkesesuaian dengan Prinsip 4 Deklarasi Stockholm 1972 yang sangat memengaruhi materi terkait lingkungan hidup dan sumber daya alam dalam UNCLOS. Dalam merespon kondisi tersebut, WCS memusatkan strateginya pada pencapaian tiga tujuan konservasi: (1) pengelolaan proses ekologi/ekosistem esensial dan sistem penyangga kehidupan; (2) pelindungan keragaman genetik; dan (2) pemanfaatan spesies dan ekosistem secara berkelanjutan. Dalam bahasa aslinya: maintenance of essential ecological processes and life-support systems; (2) preservation of genetic diversity; dan (3) sustainable utilization of species and ecosystem.

42 Menurut Philippe Sands, WCS mempengaruhi perkembangan hukum internasional dan memberi petunjuk bagi negara-negara untuk membangun strategi konservasi. Adapun tujuan UNCLOS adalah membangun kerangka hukum yang berlaku atas lautan dan samudera untuk memfasilitasi komunikasi internasional, mendukung pemanfaatan laut dan sumber dayanya secara damai, pemanfaatan sumber daya laut yang berimbang dan efisien, konservasi sumber daya hayati laut, serta penelitian, pelindungan dan preservasi lingkungan laut. Lihat: Sands, op. cit., hlm. 47 dan 396; Preamble UNCLOS.

43 Meskipun UNCLOS 1982 tidak secara langsung mengatur objek SDG laut, tetapi terdapat pengaturan mengenai penelitian ilmiah kelautan (marine scientific research) yang ditujukan untuk mendukung penanganan kelaparan, pewujudan ketahanan pangan, konservasi lingkungan laut dunia dan sumber daya alam yang ada di dalamnya, memprediksi dan merespon perubahan alam, serta mendukung pembangunan berkelanjutan. Semua hal tersebut sama dengan fungsi dari pemanfaatan SDG sehingga pengaturan tentang marine scientific research dapat dikaitkan dengan pemanfaatan SDG laut yang pada hakikatnya dilakukan melalui penelitian sebagai tahap awalnya. Lihat: United Nations, "Marine Scientific Research: a revised guide to the implementation of the relevant provisions of the United Nations Convention on the Law of the Sea," (United Nations, New York, 2010).

Lihat bagian 5. Pelindungan SDG Laut. 
pemanfaatan SDG. ${ }^{45}$ Oleh karena itu, berbicara mengenai konservasi SDG laut di wilayah Indonesia akan merujuk pada CBD.

UNCLOS dan CBD menaungi pengaturan yang berkesesuaian dengan konsep pembangunan berkelanjutan. Konsep pembangunan berkelanjutan menghendaki pembangunan harus mampu memenuhi kebutuhan generasi sekarang tanpa menggangu kemampuan generasi mendatang untuk memenuhi kebutuhannya. ${ }^{46}$ Konsep ini mulai didengungkan sejak $1980-a n,{ }^{47}$ beriringan dan berkesinambungan dengan perkembangan WCS dan UNCLOS.

Menurut Sands, pembangunan berkelanjutan terbentuk dari empat komponen yaitu: ${ }^{48}$ prinsip keadilan intergenerasi ${ }^{49}$; prinsip pemanfaatan berkelanjutan ${ }^{50}$; prinsip intragenerasi ${ }^{51}$; dan prinsip integrasi ${ }^{52}$. Pembangunan berkelanjutan mempunyai makna yang lebih luas dari sekedar perlindungan lingkungan hidup karena mencakup dimensi sosial dan ekonomi dalam pembangunan. Tetapi jelas keempat prinsip yang menjadi komponen dari pembangunan berkelanjutan ini berlandaskan pada cita-cita keadilan lingkungan hidup yang harus terintegrasi dalam agenda pembangunan. ${ }^{53}$

45 Pasal 1 CBD: "The objectives of this Convention, to be pursued in accordance with its relevant provisions, are the conservation of biological diversity, the sustainable use of its components and the fair and equitable sharing of the benefits arising out of the utilization of genetic resources, including by appropriate access to genetic resources and by appropriate transfer of relevant technologies, taking into account all rights over those resources and to technologies, and by appropriate funding." [huruf cetak tebal ditambahkan oleh penulis].

46 World Commission on the Environment and Development, Report of the World Commission on Environment and Development: Our Common Future, (Oxford/New York: Oxford University Press), 1987.

47 Sands, op. cit.,hlm. 252.

$48 \quad$ Ibid, hlm. 253.

49 Prinsip intergenerasi merujuk pada kebutuhan untuk menjaga SDA sesuai aslinya untuk kepentingan generasi mendatang. Menurut Langhelle, keadilan intra generasi merupakan prioritas pertama dari pembangunan berkelanjutan. Keadilan intra generasi menunjukkan komitmen negara-negara terhadap keadilan yang mencakup redistribusi dari pihak yang kaya kepada pihak yang miskin baik dalam level nasional maupun internasional. Lihat: Indonesian Center for Environmental Law dan Pusdiklat Teknis Peradilan MA RI, "Materi Ajar Sertifikasi Hakim Lingkungan Hidup", (ICEL, 2014), hlm. 67 yang mengutip Oluf Langhelle,"Sustainable Development and Social Justice: Expanding the Rawlsian Framework of Global Justice," Environmental Values, Vol. 9, 2000, hlm. 300.

50 Pemanfaatan SDA dengan cara yang hati-hati, berkelanjutan, rasional, bijak dan pantas.

51 Pemanfaatan SDA dilakukan secara berimbang di mana pemanfaatan yang dilakukan suatu negara harus memperhatikan kebutuhan negara lain (bisa juga diartikan dalam konteks wilayah: pemanfaatan yang dilakukan di suatu wilayah harus memperhatikan kebutuhan masyarakat di wilayah lain).

52 Pengintegrasian pertimbangan-pertimbangan lingkungan dalam rencana, program dan kegiatan ekonomi dan pembangunan.

53 Ibid. 
Interpretasi atas masing-masing prinsip sangat luas dan tidak baku sehingga ada banyak pendapat ahli yang telah menerjemahkannya. Namun di saat bersamaan, keempat prinsip tersebut tidak terpisahkan satu dengan yang lainnya. ${ }^{54}$ Tulisan ini tidak akan menjelaskan secara mendalam masing-masing prinsip tersebut, akan tetapi mengombinasikan keempat prinsip atau menggunakan salah satunya dengan catatan tidak ada satu prinsip yang tidak memiliki relasi dengan prinsip yang lain.

\section{Penguasaan Negara atas SDG Laut ${ }^{55}$}

Kedaulatan Indonesia di perairan nusantara meliputi laut teritorial, perairan kepulauan, dan perairan pedalaman serta ruang udara di atas wilayah perairan tersebut berikut dasar laut dan tanah yang berada di bawahnya termasuk juga sumber kekayaan alam terkandung di dalamnya. ${ }^{56}$ Penentuan kedaulatan laut tersebut sesuai dengan UNCLOS.

Wilayah Indonesiajuga mencakup ZEE dan Landas Kontinen. Di ZEE, Indonesia mempunyai dan melaksanakan hak berdaulat untuk melakukan pengelolaan dan konservasi SDA hayati dan non hayati dari dasar laut dan tanah di bawahnya serta air di atasnya. ${ }^{57}$ Indonesia juga mempunyai yurisdiksi yang berhubungan dengan penelitian ilmiah mengenai kelautan dan perlindungan dan pelestarian lingkungan laut di ZEE-nya. ${ }^{58}$

Komitmen Indonesia dengan masyarakat internasional dalam melindungi SDG secara de jure dimulai sejak ratifikasi CBD. ${ }^{59}$ Bentuk penguasaan negara atas

54 Sands, op. cit., hlm. 254.

55 Lihat Tabel Penguasaan Negara atas SDG laut menurut UNCLOS dan CBD pada Lampiran 1.

56 Indonesia (b), Undang-Undang tentang Perairan Indonesia, UU No. 6 Tahun 1996, LN Tahun 1996 No. 73, Pasal 4.

57 Indonesia (c), Undang-Undang tentang Zona Ekonomi Eksklusif Indonesia, UU No. 5 Tahun 1983, Pasal 4 ayat (1) huruf a, sesuai dengan UNCLOS 1982, Pasal 56 ayat 1 huruf (a) dan (b). Di ZEE negara mempunyai hak berdaulat untuk melakukan eksplorasi dan eksploitasi, pengelolaan dan konservasi SDA hayati dan non hayati dari dasar laut dan tanah di bawahnya serta air di atasnya dan kegiatan-kegiatan lainnya untuk eksplorasi dan eksploitasi ekonomis zona tersebut, seperti pembangkit tenaga dari air, arus dan angin.

58 Ibid, Pasal 4 ayat (1) huruf b. Selengkapnya, di ZEE negara mempunyai yurisdiksi untuk melakukan kegiatan yang berhubungan dengan pembuatan dan penggunaan pulau-pulau buatan, instalasi-instalasi dan bangunan lainnya; penelitian ilmiah mengenai kelautan; serta perlindungan dan pelestarian lingkungan laut.

59 Indonesia (d), Undang-Undang tentang Pengesahan United Nations Convention on Biological Diversity (Konvensi Perserikatan Bangsa-Bangsa Mengenai Keanekaragaman Hayati), UU No. 5 Tahun 1994. 
SDG menurut CBD didasarkan pada sovereign right (hak berdaulat). ${ }^{60}$ Menurut IUCN, hak berdaulat yang dimaksud dalam CBD menekankan bahwa kedaulatan negara diimbangi dengan kewajiban yang timbul karena kedaulatan itu sendiri. Hak berdaulat juga memberi penegasan bahwa konservasi SDA hayati merupakan common concern bagi seluruh masyarakat internasional. ${ }^{61}$

Sebagai negara anggota CBD dan UNCLOS, Indonesia tentunya harus menyesuaikan kebijakan pelestarian SDG laut dengan kedua instrumen tersebut. Semua pengaturan dalam CBD yang bersinggungan dengan lingkungan laut harus memperhatikan ketentuan-ketentuan yang ada dalam UNCLOS. ${ }^{62}$

UNCLOS membedakan penguasaan negara ke dalam tiga bentuk yaitu kedaulatan, hak berdaulat, dan yurisdiksi. Sedangkan CBD hanya mengenal satu, yakni hak berdaulat. Komponen SDG laut di wilayah perairan dalam, kepulauan, dan teritorial Indonesia masuk dalam kedaulatan negara tetapi dilakukan dengan memperhatikan batasan menurut hak berdaulat yaitu sepanjang tidak menimbulkan kerugian bagi negara lain. Sementara dalam pengaturan UNCLOS maupun CBD, tidak dijelaskan apakah SDG laut yang ada dalam wilayah ZEE dan Landas Kontinen termasuk objek yang diatur dalam CBD atau tidak mengingat ZEE dan Landas Kontinen berada di luar kedaulatan mutlak negara pantai. Rezim penguasaan yang ada pada kedua wilayah tersebut menurut UNCLOS berdasarkan pada hak atau

60 Pasal 3 CBD: "States have, in accordance with the Charter of the United Nations and the principles of international law, the sovereign right to exploit their own resources pursuant to their own environmental policies, and the responsibility to ensure that activities within their jurisdiction or areas beyond the limits of national jurisdiction." Pada prinsipnya hak berdaulat berarti negara memiliki kekuasaan dan yurisdiksi untuk mengatur pendistribusian, pemanfaatan, dan kepemilikan SDA yang ada di dalam wilayah kedaulatannya. Hak berdaulat atas SDG dapat diartikan sebagai hak negara untuk mengelola SDG sebagai public property untuk sebesarbesar kemakmuran rakyat saat ini tanpa mengurangi hak generasi yang akan datang baik dalam kualitas maupun kuantitasnya. Lihat: (1) Carlos M. Correa, "Sovereign and Property Rights over Plant Genetic Resources," disampaikan dalam FAO background study paper No. 2, Commission on Plant Genetic Resources, First Extraordinary Session, (Roma, 7-11 November 1994) sebagaimana dikutip Isna Fatimah,"Hak Berdaulat atas SDG Tanaman untuk Pangan dan Pertanian," (Skripsi: Fakultas Hukum Universitas Indonesia, 2013), hlm. 11. (2) Efridani Lubis, "Penerapan Konsep Sovereign Right dan Hak Kekayaan Intelektual dalam Perspektif Perlindungan dan Pemanfaatan SDG Indonesia," (Disertasi: Universitas Indonesia, 2009).

61 Glowka (b), op. cit., hlm. 3.

62 Pasal 22 ayat (2) CBD menyatakan "Contracting Parties shall implement this Convention with respect to the marine environment consistently with the rights and obligations of States under the law of the sea." Lihat: Wolfrum, R. And Matz, N, "The interplay of the United Nations Convention on the Law of the Sea and the Convention on Biological Diversity," Max Planck Yearbook of United Nations Law, vol. 4, pp475-476 sebagaimana dikutip oleh Alexander Proelss, 'ABS in Relation to Marine GRs' dalam Gerd Winter dan Evanson Chenge Kamau, Genetic Resources, Traditional Knowledge and the Law: Solutions for Access and Benefit Sharing, (London: Earthscan, 2009), hlm. 59. 
hak eksklusif yang secara limitatif mengatur kewenangan apa saja yang dimiliki negara pantai. ${ }^{63}$ Sementara CBD hanya menyatakan bahwa negara mempunyai hak berdaulat atas komponen keanekaragaman hayati yang berada di dalam wilayah yurisdiksi nasional. ${ }^{64}$

Cakupan yurisdiksi yang dimaksud pada CBD bila diartikan berdasarkan kedaulatan negara ${ }^{65}$ berarti bahwa negara mempunyai hak berdaulat hanya terhadap komponen keanekaragaman hayati yang ada pada yurisdiksi nasional. Hukum nasional dan perjanjian perbatasan antar negara-lah yang pada akhirnya benar-benar bisa menentukan yurisdiksi nasional tersebut. Meski demikian, hak berdaulat atas ZEE dan Landas Kontinen memberikan keistimewaan (privilege) kepada negara pantai sehingga negara lain yang hendak melakukan kegiatan di wilayah tersebut harus memperoleh izin dari negara pantai. Oleh karenanya, SDG laut yang berada di ZEE dan Landas Kontinen dapat dikatakan masuk dalam 'national jurisdiction.' ${ }^{6}$ Pemahaman ini penting mengingat SDG laut paling potensial sangat banyak ditemukan di wilayah deep sea bed yang letaknya sebagian besar ada di lebih dari 12 mil wilayah laut negara pantai dan berbatasan dengan wilayah laut negara tetangga/ jalur laut internasional. ${ }^{67}$

Tantangan dalam pelaksanaan kedaulatan negara atas pelestarian SDG laut adalah menerjemahkannya dalam skala nasional. Pelestarian SDG laut, sebagaimana telah dijelaskan dalam pendahuluan, tidak bisa dipisahkan dari pelestarian biota, spesies dan ekosistemnya. Oleh karena itu jelas bahwa SDG laut, berdasarkan Pasal 33 ayat (3) UUD NRI 1945, merupakan bagian dari SDA yang dikuasai oleh negara untuk sebesar-besar kemakmuran rakyat. Sehingga pada tingkat nasional,

63 Pasal 60 dan Pasal 246 UNCLOS.

64 Pasal 4 CBD: "Subject to the rights of other States, and except as otherwise express provided in this Convention, the provision of this Convention apply in relation to each Contracting Party:(a) in the case of components of biological diversity, in areas within the limits of its national jurisdiction; and (b) in the case of processes and activities, regardless of where their effects occur, carried out under its jurisdiction or control, within the area of its jurisdiction or beyond the limits of national jurisdiction."

65 Phillipe Sands merangkum kedaulatan negara atas SDA dan lingkungan dalam teritori yang terdiri atas: (1)daratan di dalam batas-batas negaranya, termasuk lapisan tanah di bawahnya; (2) perairan dalam seperti danau, sungai dan kanal (Pasal 8 UNCLOS); (3) laut teritorial yang berbatasan dengan pantai, termasuk dasar laut, lapisan tanah di bawahnya serta SDA di dalamnya (Pasal 2 dan untuk negara kepulauan Pasal 48 UNCLOS); (4) ruang udara di atas daratan, perairan dalam dan laut teritorial sampai batas dimulainya rezim hukum ruang angkasa (Oppenheim, vol 1); dan hak berdaulat serta yurisdiksi terbatas di zona tambahan, landas kontinen dan zona ekonomi eksklusif. Lihat: Sands, op. cit., hlm, 13-14.

66 Winter dan Kamau, op. cit., hlm. 61-62.

67 Kirsten E. Zewers, “Debated Heroes from the Deep Sea - Marine Genetic Resources," (WIPO Magazine, April 2008), diakses dari http://www.wipo.int/wipo_magazine/ en/2008/02/ article 0008.html pada 3 Juni 2015 pukul 9.40 WIB. 
negara - yang dalam hal ini merujuk pada pemerintah - menguasai SDG laut untuk kepentingan rakyatnya.

Penafsiran terhadap penguasaan negara dalam Pasal 33 UUD NRI 1945 ini telah dilakukan oleh Mahkamah Konstitusi (MK) dalam beberapa putusan. ${ }^{68} \mathrm{MK}$ menafsirkan bahwa penguasaan negara diejawantahkan dalam bentuk wewenang pemerintah untuk: (1) merumuskan kebijakan (beleid); (2) melakukan tindakan pengurusan (bestuursdaad); (3) melakukan pengaturan (regelendaad); (4) melakukan pengelolaan (beheersdaad), dan/atau (5) melakukan pengawasan (toezichthoudendaad) ${ }^{69}$ Mengingat SDG laut pada prinsipnya merupakan milik seluruh rakyat Indonesia maka pemerintah dalam melaksanakan wewenangnya harus atas dasar tujuan menyejahterakan rakyat.

UNCLOS dan CBD lebih banyak memberikan petunjuk bagi negara untuk membuat kebijakan, pengaturan dan pengawasan. Akan tetapi pemerintah perlu mempertimbangkan untuk bertindak sebagai pengelola dan/atau pengurus dalam pemanfaatan dan pelindungan karena SDG laut merupakan kekayaan alam yang relatif sulit dijangkau namun potensinya sangat besar untuk kebutuhan masyarakat.

\section{Pemanfaatan SDG Laut}

Pemanfaatan SDG dilakukan pertama-tama melalui penelitian yang dapat ditujukan untuk kepentingan non-komersial atau komersial. CBD menjelaskan pemanfaatan SDG sebagai: "...the process of researching their beneficial properties and using them to increase scientific knowledge and understansing, or to develop commercial products." 70

Keunikan dari pemanfaatan SDG adalah pemanfaatan yang dilakukan bukan dengan penggunaan komoditasnya melainkan pemanfaatan materi dan informasi genetik yang terkandung di dalamnya. Secara khusus dalam Explanatory Guide to the Nagoya Protocol dijelaskan bahwa: "...in CBD context, genetic resources are biological resources needed or used for their genetic material and not for their other attributes."71

68 Diantaranya putusan MK No. 001/PUU-I/2003 tentang pengujian UU No. 20 tahun 2002 tentang Ketenagalistrikan dan Putusan MK No. 002/PUU-I/2003 tentang pengujian UU No. 22 tahun 2001 tentang Minyak dan Gas Bumi.

69 Putusan MK No. 85/PUU-XI/2013 tentang pengujian UU No. 7 tahun 2004 tentang Sumber Daya Air.

70 CBD Secretariat (b), "Uses of Genetic Resources," (UNCBS Factsheet, 2010), hlm. 3.

71 Greiber, et. al., op. cit., hlm. 6. Istilah material merujuk pada sifat atau informasi yang dibawa oleh gen, bukan wujud fisiknya. Contoh yang diberikan dalam A Guide to Nagoya Protocol 
Menentukan suatu penelitian merupakan penelitian atas SDG harus diidentifikasi dari tujuan penelitiannya. Sepanjang penelitian dilakukan untuk mengeksplorasi materi dan informasi genetik, maka penelitian tersebut masuk dalam kategori pemanfaatan SDG. Barulah pemanfaatan SDG dapat diidentifikasi lagi dalam dua jenis: penelitian dasar non-komersial (basic research) dan komersialisasi produk (commercialization of products). ${ }^{72}$

SDG laut mempunyai keunikan dibandingkan dengan SDG yang ada di daratan terutama karena habitatnya yang relatif berada di luar jangkauan manusia. Hal ini akan menyebabkan (1) kontrol terhadap upaya perlindungan dan kontrol terhadap akses ke SDG laut lebih sulit dilakukan; (2) menentukan pemilik pengetahuan yang terasosiasi dengan SDG laut memerlukan pembuktian-pembuktian ilmiah dengan teknologi yang lebih tinggi. Akibatnya, penentuan pihak yang berhak memperoleh pembagian keuntungan lebih kompleks karena boleh jadi spesies yang sama hidup tersebar di perairan di wilayah kedaulatan lebih dari satu negara atau di wilayah laut lepas.

Bicara tentang aspek hukum dalam manajemen pemanfaatan SDG laut dalam CBD dan UNCLOS akan mengerucut setidaknya pada 2 hal, ${ }^{73}$ yaitu:
a. Penelitian ilmiah kelautan;
b. Akses dan pembagian keuntungan yang adil dan berimbang (ABS).

\section{4.a. Penelitian Ilmiah Kelautan}

Indonesia sebagai negara pantai mempunyai hak eksklusif untuk mengatur dan melaksanakan penelitian ilmiah kelautan $^{74}$ di wilayah teritorialnya. Pihak yang hendak melakukan penelitian ilmiah kelautan di wilayah tersebut harus mendapatkan persetujuan (express consent) dan tunduk pada kondisi-kondisi yang

adalah akses ke hutan untuk mengambil kayu atau ekstraksinya yang dimanfaatkan untuk kebutuhan konvensional tidak termasuk pemanfaaan SDG. Sebaliknya, jika tujuan diambilnya kayu atau ekstraksi tersebut untuk diteliti lebih lanjut manfaatnya, maka pemanfaatan SDG menurut CBD berlaku.

72 Greiber, et. al., op. cit., hlm. 4.

73 Dipilih oleh penulis.

74 Majelis Umum Perserikatan Bangsa-Bangsa terus-menerus menggarisbawahi bahwa penelitian ilmiah kelautan dilakukan untuk tujuan-tujuan global seperti mendukung penanganan kelaparan, pewujudan ketahanan pangan, konservasi lingkungan laut dunia dan SDA yang ada di dalamnya, memprediksi dan merespon perubahan alam, serta mendukung pembangunan berkelanjutan. Lihat: United Nations, “Marine Scientific Research: a revised guide to the implementation of the relevant provisions of the United Nations Convention on the Law of the Sea," (United Nations, New York, 2010). 
ditentukan Indonesia. ${ }^{75}$ Negara lain yang hendak melakukan penelitian ilmiah kelautan di wilayah ZEE Indonesia harus memperoleh persetujuan terlebih dahulu dan melaksanakan penelitian sesuai syarat-syarat yang ditetapkan oleh Pemerintah Indonesia, ${ }^{76}$ serta diwajibkan untuk memberikan keterangan lengkap mengenai tujuan dari penelitian tersebut. ${ }^{77}$ Sementara dalam CBD, penelitian terhadap SDG sering dikenal dengan istilah bioprospecting. ${ }^{78}$ Berdasarkan CBD, penelitian ilmiah kelautan dengan SDG laut sebagai objeknya atau bioprospecting akan diikuti mekanisme ABS.79

Pengaturan terkait penelitian ilmiah kelautan di Indonesia dapat ditemukan pada beberapa undang-undang antara lain: (1) Undang-Undang Nomor 8 Tahun 2012 tentang Sistem Nasional Penelitian, Pengembangan dan Penerapan Ilmu Pengetahuan (UU 18/2002) ${ }^{80}$; (2) Undang-Undang Nomor 31 Tahun 2004 tentang

75 Pasal 241 UNCLOS menegaskan: "Marine scientific research activities shall not constitute the legal basis for any claim to any part of the marine environment or its resources." Sehingga dalam hal pengaturan tentang prosedur, batasan, dan implementasi penelitian ilmiah kelautan dikembalikan lagi kepada hukum nasional negara pantai. Lihat juga: Pasal 245 UNCLOS.

76 UNCLOS mengatur lebih rinci tentang penelitian ilmiah kelautan di setiap jenis wilayah laut. Pada intinya negara pantai berhak memberikan persetujuan atau menolak permohonan melakukan penelitian ilmiah kelautan yang diajukan oleh negara atau subjek hukum asing di wilayah teritorial sampai dengan ZEE dan Landas Kontinen. Adapun penelitian ilmiah kelautan yang dimaksud dalam UNCLOS tunduk pada empat prinsip umum yaitu:

1. Diselenggarakan secara eksklusif untuk tujuan perdamaian;

2. Menggunakan metode ilmiah dan dilakukan untuk tujuan yang sesuai dengan UNCLOS;

3. Tidak bertentangan atau mengganggu kegiatan pemanfaatan laut lain yang sudah mempunyai legitimasi dan harus menghormati kegiatan tersebut;

4. Patuh pada semua peraturan yang relevan dengan UNCLOS termasuk mengenai perlindungan dan pelestarian lingkungan laut.

Lihat: United Nations, "Marine Scientific Research: A revised guide to the implementation of the relevant provisions of the United Nations Convention on the Law of the Sea," (New York: United Nations Division for Ocean Affairs and the Law of the Sea Office of Legal Affairs, 2010), hlm. 6-7; Indonesia (c), op. cit., Pasal 7.

77 Pasal 248-249 UNCLOS. Walaupun demikian, lingkup penelitian ilmiah kelautan yang dimaksud dalam UNCLOS tidak mencakup penelitian untuk kepentingan komersil. Sehingga untuk penelitian SDG Laut dengan tujuan komersil dapat merujuk pada CBD di mana negara mempunyai kewenangan memberikan atau menolak permintaan akses ke SDG-nya. Lihat: Alexander Proelss, 'ABS in Relation to Marine GRs' dalam Gerd Winter dan Evanson Chenge Kamau, Genetic Resources, Traditional Knowledge and the Law: Solutions for Access and Benefit Sharing, (London: Earthscan, 2009), hlm. 61-62.

78 Bioprospecting adalah kegiatan pencarian manfaat baru yang mempunyai potensi ekonomi dari material biologi. Penelitian ilmiah kelautan dengan objek SDG atau pengetahuan tradisional biasanya menjadi informasi awal yang sangat berguna bagi kegiatan bioprospecting. Lihat: Greiber, et. al., op. cit., hlm. 212.

79 Pengaturan tentang ABS sendiri tidak secara eksplisit diatur dalam UNCLOS. Akan tetapi dalam perkembangannya, ABS atas pemanfaatan SDG kemudian diatur dalam CBD.

80 Indonesia (e), Undang-Undang tentang Sistem Nasional Penelitian, Pengembangan, dan Penerapan Ilmu Pengetahuan dan Teknologi, UU No. 18 Tahun 2002, LN 2002 No. 84, TLN No. 4219. 
Perikanan (UU 31/2004) ${ }^{81}$; dan (3) Undang-Undang No. 32 Tahun 2014 tentang Kelautan (UU 32/2014)..$^{82}$

UU 18/2002 tidak secara spesifik mengatur tentang penelitian ilmiah kelautan namun menjadi payung hukum bagi kegiatan penelitian di Indonesia. ${ }^{83}$ Pasal 17 ayat (4) UU 18/2002 mengatur agar peneliti asing yang melakukan penelitian di Indonesia harus mendapatkan izin tertulis dari instansi pemerintah yang berwenang. ${ }^{84}$ Namun jenis penelitian SDG laut tidak secara spesifik disebutkan dalam UU tersebut maupun peraturan turunnya. Selain itu, UU ini tidak secara jelas membedakan pengaturan terhadap kegiatan penelitian ${ }^{85}$ (bisa dipadankan dengan penelitian non-komersial) dengan pengembangan ${ }^{86}$ (bisa dipadankan dengan penelitian komersial).

81 Indonesia (f), Undang-Undang tentang Perikanan, UU No. 31 Tahun 2004, LN 2004 No. 114 jo. Undang-Undang tentang Perubahan atas Undang-Undang Nomor 31 Tahun 2004 tentang Perikanan, UU No. 45 Tahun 2009, LN 2009 No. 154.

82 Indonesia (g), Undang-Undang tentang Kelautan, UU No. 32 Tahun 2014, LN 2014 No. 294, TLN No. 5603.

83 Pasal 22 ayat (2) UU 18/2002 misalnya, memerintahkan Pemerintah mengatur perizinan bagi pelaksanaan kegiatan penelitian, pengembangan dan penerapan ilmu pengetahuan dan teknologi yang berisiko tinggi dan berbahaya dengan memperhatikan standar nasional dan ketentuan yang berlaku secara internasional.

84 Bunyi Pasal 17 ayat (4) UU 18/2002 selengkapnya: “ Perguruan tinggi asing, lembaga litbang asing, badan usaha asing, dan orang asing yang tidak berdomisili di Indonesia yang akan melakukan kegiatan penelitian dan pengembangan di Indonesia yang akan melakukan kegiatan penelitian dan pengembangan di Indonesia harus mendapatkan izin tertulis dari instansi pemerintah yang berwenang. Penjelasan Pasal 17 ayat (4) UU 18/2002 menyatakan: tujuan izin khusus peneliti asing ini untuk menghindari dilakukannya: (a) kegiatan yang mengakibatkan kekayaan hayati dan non hayati milik negara dimanfaatkan secara tidak bertanggung jawab oleh pihak asing, dan (b) kegiatan yang berpotensi menimbulkan wabah, merusak fungsi lingkungan hidup, gangguan sosial kemasyarakatan, atau gangguan lain yang merugikan; Setiap permohonan izin yang dimintakan kepada instansi pemerintah berwenang harus melalui penilaian yang memperhatikan dan mempertimbangkan kemanfaatan ilmu pengetahuan dan teknologi, hubungan luar negeri, kelestarian lingkungan hidup, politik, dan pertahanan. Lihat: Pasal 4 ayat (2) Peraturan Pemerintah Nomor 41 Tahun 2006 tentang Perizinan Melakukan Kegiatan Penelitian dan Pengembangan bagi Perguruan Tinggi Asing, Lembaga Penelitian dan Pengembangan Asing, Badan Usaha Asing, dan Orang Asing; Dalam hal penelitian masuk dalam kategori berisiko tinggi dan berbahaya di bidang kelautan dan perikanan, instansi pemerintah yang berwenang kementerian bidang kelautan dan perikanan. Lihat: Penjelasan Pasal 3 ayat (2) Peraturan Pemerintah Nomor 48 Tahun 2009 tentang Perizinan Pelaksanaan Kegiatan Penelitian, Pengembangan, dan Penerapan Ilmu Pengetahuan dan Teknologi yang Berisiko Tinggi dan Berbahaya.

85 Penelitian adalah kegiatan yang dilakukan menurut kaidah dan metode ilmiah secara sistematis untuk memperoleh informasi, data, dan keterangan yang berkaitan dengan pemahaman dan pembuktian kebenaran atau ketidakbenaran suatu asumsi dan/atau hipotesis di bidang ilmu pengetahuan dan teknologi serta menarik kesimpulan ilmiah bagi keperluan kemajuan ilmu pengetahuan dan teknologi. Pasal 1 angka 4 UU 18/2002.

86 Pengembangan adalah kegiatan ilmu pengetahuan dan teknologi yang bertujuan memanfaatkan kaidan dan teori ilmu pengetahuan yang telah terbukti kebenarannya untuk meningkatkan fungsi, manfaat, dan aplikai ilmu pengetahuan dan teknologi yang telah ada atau menghasilkan teknologi baru. Pasal 1 angka 5 UU 18/2002. 
Sementara Undang-Undang Nomor 31 Tahun 2004 tentang Perikanan (UU 31/2004) hanya mengatur penelitian untuk menghasilkan pengetahuan dan teknologi yang dibutuhkan dalam pengembangan usaha perikanan. ${ }^{87}$ Lebih lanjut diatur dalam Peraturan Menteri Kelautan dan Perikanan Nomor Per.04/Men/2010 tentang Tata Cata Pemanfaatan Jenis Ikan dan Genetik Ikan (Permen KKP 04/2010) bahwa pemanfaatan SDG laut harus dilakukan atas izin Direktur Jenderal. ${ }^{88}$ Meski demikian, peraturan tersebut tidak membedakan pengaturan izin pemanfaatan jenis/spesies dengan izin pemanfaatan genetik. ${ }^{89}$

Pengaturan lain berkenaan dengan pemanfaatan SDG laut termuat dalam UU 32/2014 yang mengatur tentang industri bioteknologi kelautan. ${ }^{90}$ Meskipun menggunakan istilah industri, tetapi tiga dari lima tujuan industri bioteknologi

87 "Pemerintah mengatur, mendorong, dan/atau menyelenggarakan penelitian dan pengembangan perikanan untuk menghasilkan pengetahuan dan teknologi yang dibutuhkan dalam pengembangan usaha perikanan agar lebih efektif, efisien, ekonomis, berdaya saing tinggi, dan ramah lingkungan, serta menghargai kearifan tradisi/budaya lokal." [huruf cetak miring ditambahkan oleh penulis]. Lihat: Indonesia (h), Undang-Undang tentang Perubahan atas Undang-Undang Nomor 31 Tahun 2004 tentang Perikanan, UU No. 45 Tahun 2009, LN 2009 No. 154, Pasal 1 angka 8; Pasal 52.

88 Direktur Jenderal yang dimaksud adalah direktur jenderal bidang kelautan, pesisir dan pulau-pulau kecil (namun saat ini kewenangannya berada di bawah Direktorat Jenderal Pengelolaan Ruang Laut). Lihat: Menteri Kelautan dan Perikanan RI, Peraturan Menteri Kelautan dan Perikanan tentang Tata Cara Pemanfaatan Jenis Ikan dan Genetik Ikan, Permen KKP No. Per.04/MEN/2010, Pasal 1 angka 9 jo. Menteri Kelautan dan Perikanan RI, Peraturan Menteri Kelautan dan Perikanan tentang Organisasi dan Tata Kerja Kementerian Kelautan dan Perikanan, Permen KKP No. 23/PERMEN-KP/2015.

89 Jenis izin dalam Permen 4/2010 meliputi surat izin penelitian dan pengembangan, surat izin pengembangbiakan; surat izin perdagangan; surat izin aquaria; surat izin pertukaran; surat izin pemeliharaan untuk kesenangan; dan surat izin pengambilan ikan dari alam. Permen KKP ini pada intinya hanya menyatakan setiap izin tersebut diberikan untuk permohonan jenis ikan dan genetik ikan yang memenuhi syarat formil maupun substantif. Selain bicara mengenai pemanfaatan, Permen KKP 04/2010 mengatur bahwa pemanfaatan SDG laut bertujuan menciptakan tertib pemanfaatan berdasarkan prinsip kehati-hatian dan dasar ilmiah guna mencegah terjadinya kerusakan dan.atau degradasi populasi sumber daya ikan. Kemudian yang menarik adalah batasan bagi penelitian dan pengembangan yang dilakukan orang dan/atau badan hukum asing hanya dapat diberikan untuk keperluan pengembangbiakan dalam upaya konservasi jenis ikan dan genetik ikan dan/ atau reintroduksi ke habitat alam. Ketentuan ini bisa mengundang kontroversi bagi pihak asing yang hendak melakukan penelitian dan pengembangan untuk kepentingan komersial dan berpotensi membatasi atau menghambat semangat penelitian ilmiah. Di samping itu, mekanisme penegakan pengawasan atas akses ke SDG laut secara umum masih belum diperkuat, sehingga banyak regulasi hulu yang sudah cukup baik (perizinan) bisa jadi tidak terkendali pada implementasi di hilirnya (pelaksanaan di lapangan). Lihat: Pasal 2 ayat (1); Pasal 17 ayat (2); dan Pasal 40 Permen KKP 04/2010.

90 Pasal 26 ayat (3) UU 32/2014. Adapun yang dimaksud dengan industri bioteknologi dalam UU ini adalah seperangkat teknologi yang mengadaptasi dan memodifikasi organisme biologis, proses, produk, dan sistem yang ditemukan di alam untuk tujuan memproduksi barang dan jasa (Penjelasan Pasal 25 ayat (2) UU 32/2014). 
berorientasi pada pelestarian. ${ }^{91}$ Sayangnya, UU ini tidak memerintahkan untuk mengatur lebih lanjut ketentuan tentang industri bioteknologi.

Berdasarkan uraian umum tentang ketiga UU tersebut, terlihat bahwa pengaturan tentang penelitian ilmiah kelautan khusus SDG laut atau bioprospecting belum cukup lengkap. Padahal di Indonesia, pengaturan teknis sangat penting untuk menggiring pejabat administrasi melakukan tugas pengendalian dan pengawasan. Di samping itu, pengaturan tentang penelitian ataupun pemanfaatan yang sudah ada belum dikorelasikan dengan aspek hukum pasca penelitian yang melekat seperti pelindungan pengetahuan tradisional ${ }^{92}$ dan hak kekayaan intelektual, serta mekanisme pembagian keuntungan yang adil dan berimbang.

Hal lain yang penting diatur adalah tentang pelaksanaan, pengendalian dan pengawasan penelitian non-komerisal dan komersial. Harus diakui bahwa membedakan kegiatan penelitian di wilayah laut yang bertujuan murni untuk pengembangan ilmu dengan penelitian komersial sangat sulit dilakukan, terutama bila hasil pengembangannya ternyata bermanfaat untuk kepentingan seluruh umat manusia. ${ }^{93}$ Namun tetap saja, kejelasan pengaturan tentang kegiatan penelitian penting salah satunya untuk kemudian mengatur dan mengimplementasikan mekanisme ABS dan mencegah terjadi biopiracy ${ }^{94}$.

91 Adapun kelima tujuan industri bioteknologi dimaksud meliputi: (a) mencegah punahnya biota laut akibat eksplorasi berlebih; (b) menghasilkan berbagai produk baru yang mempunyai nilai tambah; (c) mengurangi ketergantungan impor dengan memproduksi berbagai produk substitusi impor; (d) mengembangkan teknologi ramah lingkungan pada setiap industri bioteknologi Kelautan; dan (e) mengembangkan sistem pengelolaan sumber daya laut secara berkesinambungan. Pasal 26 UU 32/2014.

92 Pengetahuan tradisional merupakan informasi dan teknologi yang digunakan untuk mengolah dan menggunakan SDG dalam kehidupan sehari-hari oleh masyarakat tertentu (biasanya masyarakat adat atau lokal). Pengetahuan tradisional dimaksud sejatinya memiliki karakteristik ilmiah, empiris, eksperimental, holistik dan sistematis, meskipun kerap dianggap primitif. Lihat: Jack K. githae,"Potential of TK for Conventional Therapy: Prospects and Limits," dalam Evanson C. Kamau dan Gerd Winter, dalam Miranda Risang Ayu, Harry Alexander dan Wina Puspitasari, Hukum Sumber Daya Genetik, Pengetahuan Tradisional dan Ekspresi Budaya Tradisional di Indonesia, (PT Alumni: Bandung, 2014), hlm. 17.

93 Lyle Glowka berpandangan bahwa menentukan kriteria 'untuk kepentingan seluruh umat manusia' itu sendiri juga sulit dilakukan. Lihat: Lyle Glowka (c), "the Deepest of Ironies: Genetic Resources, Marine Scientific Research, and the Area," (The University of Chicago, 1996).

94 Biopiracy adalah istilah yang tidak resmi namun umum digunakan untuk menjelaskan suatu tindakan mengambil alih pengetahuan atas suatu SDG dari pihak yang lebih dahulu mempunyai pengetahuan tersebut dan memperoleh keuntungan darinya tanpa memberi kompensasi pada pemilik pengetahuan asal. Biopiracy diartikan sebagai pengambilalihan atau komersialisasi atas SDG dan pengetahuan yang terasosiasi dengannya yang dilakukan secara ilegal atau bertentangan dengan prinsip pembagian keuntungan. Lihat: Miguel N Alexiades dan Sarah A Laird, "Laying the Foundation: Equitable Biodiversity Research Relationships" dalam Sarah A Laird (ed), Biodiversity and Traditional Knowledge: Equitable Partnerships in Practice, (Earthscan, 2002), sebagaimana dikutip Achmad Gusman Catur Siswandi, “Marine 


\section{4.b. Akses dan Pembagian Keuntungan yang Adil dan Berimbang (ABS)}

Pengaturan lebih khusus tentang ABS terdapat dalam Protokol Nagoya ${ }^{95}$ yang sudah diratifikasi pula oleh Indonesia. ABS adalah suatu mekanisme pemberian akses terhadap pemanfaatan SDG berdasarkan prior informed concent (PIC) ${ }^{96}$ dan mutually agreed terms (MAT) ${ }^{97}$ yang diikuti dengan pembagian keuntungan adil dan seimbang atas hasil pemanfaatan SDG berupa pertukaran informasi, transfer teknologi, pengembangan kapasitas, atau pembagian keuntungan komersial. ${ }^{98}$ Tujuan sesungguhnya dari ABS adalah untuk mendorong negara asal SDG meningkatkan kapasitas dalam pemanfaatan berkelanjutan SDG. ${ }^{99}$

ABS mempunyai fungsi pengendalian atas kemungkinan pihak yang dirugikan atas pematenan SDG dan derivatifnya. ABS adalah mekanisme yang berusaha menengahi pertentangan penerapan rezim Hak Kekayaan Intelektual (HKI) atas penemuan manfaat SDG dengan kepentingan masyarakat terutama yang telah melestarikan biota yang mengandung SDG tersebut atau yang telah mempunyai pengetahuan awal tentang manfaat tersebut, meskipun tidak melalui uji ilmiah. ${ }^{100}$ Penerapan HKI atas suatu SDG harus dilakukan dengan pertimbangan yang sangat hati-hati karena akan berdampak pada akses masyarakat terhadap SDG tersebut ke depannya.

Akses dalam proses ABS di Indonesia bisa diselaraskan dengan mekanisme akses ke penelitian sebagaimana telah dijelaskan pada bagian 4.a. Hanya saja perlu diperjelas bagaimana pengaturan tentang mekanisme akses terhadap SDG laut.

Bioprospecting: International Law, Indonesia and Sustainable Development," (Thesis submitted for the degree of Doctor of Philosophy of The Australian National University, January 2013).

95 UNCBD, Nagoya Protocol on Access to Genetic Resources and the Fair and Equitable Sharing of Benefits Arising from Their Utilization to the Convention on Biological Diversity, Nagoya 29 October 2010.

96 Prior informed consent adalah mekanisme yang mewajibkan pihak yang akan mengakses SDG memberikan informasi yang cukup mengenai potensi dari SDG yang akan diakses kepada pihak-pihak yang terkait/terdampak dan otoritas yang memberikan keputusan membuka atau menurut akses agar mereka dapat memberikan keputusan yang didasarkan pada pengetahuan menyeluruh. Lihat: Winter dan Kamau, op. cit., hlm. 9.

97 Mutually agreed terms adalah mekanisme negosiasi antara para pihak yang akan memberi akses ke sumber daya gentik dengan pihak yang akan mengakses SDG tersebut untuk mencapai sebuah kesepakatan pengaksesan (an access agreement, kadang dikenal dengan material transfer agreement/perjanjian alih material). Lihat: Ibid.

98 Thomas Greiber, op. cit., hlm. 28.

99 Peter-Tobias Stoll," Access to GRs and Benefit Sharing - Underlying Concepts and the Idea of Justice" dalam Winter dan Kamau, op. cit.

100 Lihat catatan kaki 107. 
Pengaturan yang jelas mengenai kegiatan penelitian juga sangat penting untuk menentukan dalam keadaan bagaimana sebuah klaim HKI atas hasil penelitian diterima atau ditolak. Adapun akses terhadap SDG menurut CBD setidaknya harus dilakukan sesuai dengan mengedepankan keamanan lingkungan, berdasarkan MAT dan memenuhi syarat PIC. Dalam hal sampel hendak dibawa oleh peneliti, maka harus didahului penyepakatan perjanjian alih material (Material Transfer agreement) MTA). ${ }^{101}$

Komponen ABS yang sangat baru bagi peraturan perundangan di Indonesia adalah komponen pembagian keuntungan (benefit sharing) dari akses ke SDG laut. Hal yang perlu diperhatikan dalam mengatur pembagian keuntungan diantaranya adalah $^{102}$ :

a. Pihak yang berhak mendapatkan pembagian keuntungan, yang baru bisa dilakukan setelah jelas siapa pengampu (custodian) dari SDG laut. ${ }^{103}$

b. Penegasan prinsip adil dan berimbang dan pengejawantahannya dalam pembagian keuntungan.

c. Pembagian keuntungan dengan masyarakat yang mempunyai pengetahuan tradisional atas SDG laut atau yang telah melestarikan biota, spesies atau ekosistem di mana SDG laut berada. ${ }^{104}$

d. Bentuk keuntungan, yang bisa berupa moneter ${ }^{105}$ atau non-moneter ${ }^{106}$.

101 Perjanjian alih material (Material Transfer Agreement/MTA) wajib dibuat antara pengakses dengan pengampu SDG apabila pengakses hendak membawa sampel material genetik. Biasanya MTA berisi perjanjian tentang objek yang hendak dibawa/diakses, keterangan tentang para pihak (pengakses, pengampu, pemberi izin dan/atau penyedia), klausul kesepakatan tentang akses dan pembagian keuntungan, hak dan kewajiban lain para pihak, larangan mengalihkan ke pihak ketiga dan ketentuan lain sesuai dengan CBD dan Protokol Nagoya. Lihat: CBD Secretariat, Bonn Guidelines on Access to Genetic Resources and Fair and Equitable Sharing of the Benefits Arising out of their Utilization, (Montreal, 2002).

102 Ahmad Gusman Siswandi, "Kajian Terhadap Integrasi Rancangan Undang-Undang Konservasi Keanekaragaman Hayati dan Rancangan Undang-Undang Pengelolaan Sumber Daya Genetik," (Kajian yang disusun untuk pengembangan Naskah Akademik RUU Konservasi Keanekaragaman Hayati, dipublikasikan terbatas, November 2015), hlm. 18-19. Diolah kembali oleh penulis.

103 Misalnya untuk SDG laut pesisir bisa saja diampu oleh masyarakat pesisir yang terbukti secara turun temurun memanfaatkan spesies tertentu yang material genetiknya menjadi objek akses/penelitian. Namun untuk SDG laut yang belum pernah secara tradisional dimanfaatkan, berdasarkan penguasaan negara sehingga pemerintah bertindak sebagai pengampunya.

104 Idem.

105 Lihat Annex Protokol Nagoya.

106 Ibid. 
e. Kontribusi keuntungan bagi kegiatan konservasi dan pemanfaatan berkelanjutan SDG laut.

Penentuan hal-hal tersebut ketika objeknya berupa SDG laut tentu jauh lebih kompleks dari pada SDG yang ada di daratan. Kebanyakan negara yang sudah mempunyai pengaturan tentang ABS yang mencakup SDG laut tidak mengatur sekomprehensif pengaturan SDG di daratan. ${ }^{107}$ Demikian halnya dengan Indonesia, meskipun sudah mempunyai beberapa pengaturan spesifik untuk pemanfaatan SDG laut, namun pengaturan mekanisme ABS di Indonesia belum mumpuni.

Meningkatnya kesadaran akan pentingnya potensi SDG secara simultan diikuti dengan peningkatan kesadaran akan pentingnya menghargai peran pengetahuan tradisional. ${ }^{108}$ Walaupun pengetahuan tradisional yang sudah teridentifikasi lebih banyak terasosiasi dengan SDG daratan, bukan tidak mungkin ada pula pengetahuan tradisional yang terasosiasi dengan SDG lautan, terutama bagi masyarakat pesisir. ${ }^{109}$ Pelindungan pengetahuan tradisional menjadi salah satu indikator terwujudnya keadilan distributif sebagai bagian dari keadilan intra generasi, sekaligus menjadi bekal pewujudan keadilan intergenarasi.

Pengakuan terhadap pengetahuan tradisional dalam bentuk kearifan lokal secara umum sudah bisa ditemukan di beberapa peraturan perundangundangan. ${ }^{110}$ Namun pengaturannya belum terintegrasi dengan kebijakan lain, misalnya yang berkaitan dengan pelindungan HKI. Jika merujuk pada peraturan perundang-undangan bidang $\mathrm{HKI}$, pengakuan terhadap pengetahuan tradisional dan pelindungannya belum mendapat tempat. Selain itu, arahan agar pengetahuan tradisional dimanfaatkan untuk tujuan pelestarian SDG belum terlihat.

Pelaksanaan ABS atas pemanfaatan SDG laut melibatkan berbagai kewenangan yang diemban oleh berbagai instansi. ${ }^{111}$ Protokol Nagoya sendiri mengamanatkan

107 Alexander Proelss, 'ABS in Relation to Marine GRs' dalam Gerd Winter dan Evanson Chenge Kamau, Genetic Resources, Traditional Knowledge and the Law: Solutions for Access and Benefit Sharing, (London: Earthscan, 2009), hlm. 61.

108 Susete Biber-Klemm dan Danuta Szymuda Berglas, "Biodiversity and Traditional Knowledge: Factual Background and Problems," (World Trade Institute, University of Berne, and Faculty of Law, University of Basel, Maiengasse, Switzerland), hlm. 3.

109 Penggunaan rumput laut untuk bahan pangan, minyak ikan untuk vitamin dan obat-obatan merupakan beberapa contoh pemanfaatan SDA laut yang, dalam kondisi modern bisa digunakankan untuk pemanfaatan lebih lanjut SDG.

110 Diantaranya: UU No. 32 Tahun 2009 tentang Perlindungan dan Pengelolaan Lingkungan Hidup, UU No. 27 Tahun 2007 tentang Pengelolaan Wilayah Pesisir dan Pulau-Pulau Kecil (dan perubahannya), UU No. 31 Tahun 2004 tentang Perikanan (dan perubahannya), UU No. 32 Tahun 2014 tentang Kelautan.

111 Meliputi setidaknya kementerian bidang kelautan dan perikanan (yang mempunyai 
negara anggotanya menunjuk Competent National Authority ${ }^{112}$ dan National Focal Point $^{113}$ untuk memudahkan kerja sama antar negara sekaligus membantu pelaksanaan ABS di tingkat nasional. Selain itu, Protokol Nagoya secara implisit mengamanatkan negara mempunyai sistem basis data untuk inventarisasi hasil penelitian (baik publikasi maupun material fisik) dan pengawasan kegiatan ABS yang terhubung dengan Clearing House di sekretariat Protokol. ${ }^{114}$

\section{Pelindungan SDG Laut}

Meskipun desakan untuk pemanfaatanSDG melalui mekanismeABSlebih besar, satu hal yang tidak bisa dipinggirkan adalah konsentrasi pada upaya pelindungan SDG laut. Dalam CBD, kegiatan pelindungan dilakukan melalui konservasi in situ dan $e k s$ situ. ${ }^{115}$ Bicara mengenai konservasi secara in situ membutuhkan manajemen pengelolaan yang integratif dan mensyaratkan pelindungan hingga skala ekosistem. Sementara konservasi eks situ membutuhkan dukungan teknologi dan sistem basis data yang sangat handal. Kegiatan konservasi ex situ dilakukan dengan pengelolaan untuk memastikan agar pemanfaatan dilakukan secara berkelanjutan dan mampu berkontribusi melindungi proses ekologi termasuk esensi keragaman genetiknya demi keberlangsungan sumber daya alam. ${ }^{116}$

Pada prinsipnya semua negara wajib menjaga dan melestarikan lingkungan laut. ${ }^{117}$ Menurut UNCLOS, dalam melaksanakan hak berdaulatnya untuk mengeksploitasi SDA, negara tetap berkewajiban menjaga serta melestarikan

kewenangan pengaturan SDG laut), kementerian bidang riset dan teknologi (untuk izin penelitian), kementerian luar negeri.

112 Competent National Authority (CNA) adalah otorita yang mempunyai kewenangan terkait ABS. Satu negara dapat mempunyai lebih dari satu CNA. Lihat Pasal 13 Protokol Nagoya.

113 National Focal Point (NFP) adalah otorita nasional yang bertindak sebagai penghubung antara CNA dengan Sekretariat Protokol Nagoya dan/atau CBD. Lihat Pasal 13 Protokol Nagoya.

114 Clearing House adalah media pertukaran informasi terkait pelaksanaan ABS yang dibentuk Protokol Nagoya. Lihat Pasal 14 Protokol Nagoya.

115 CBD membagi konservasi dalam dua cara yaitu in situ dan ex situ. Konservasi in situ adalah konservasi ekosistem dan habitat alami serta pengelolaan dan pemulihan viabilitas populasi spesies di lingkungan alaminya, serta, untuk spesies budidaya, di lingkungan di mana mereka telah dibudidayakan. Sedangkan konservasi ex situ adalah konservasi atas komponen keanekaragaman hayati di luar habitat alaminya. Konservasi in situ untuk SDG laut biasanya dilakukan di wilayah konservasi laut sementara contoh konservasi $e k s$ situ adalah konservasi yang dilakukan di aquaria atau bank gen.

116 WCS, op. cit.

117 UNCLOS, op. cit., Pasal 192. 
lingkungan laut. ${ }^{118}$

Pemanfaatan SDG laut atas nama kebutuhan seluruh umat manusia tidak bisa menegasikan konservasi. Di sisi lain, konservasi SDG laut tidak dapat dilakukan hanya dengan pendekatan konservasi kawasan tertentu dengan paradigma menjaga keaslian kawasan tanpa intervensi pengelolaan. ${ }^{119}$ Terlebih, sebuah pemahaman yang kurang tepat bila pelaksanaan ABS hanya difokuskan untuk pemanfaatan SDG. Padahal sejatinya ABS diharapkan menjadi gerbang bagi pewujudan konservasi. ${ }^{120}$

Pelindungan terhadap SDG laut merupakan pengejawantahan prinsip intergenerasi yang konkrit. Tujuan pelindungan SDG laut, oleh karenanya adalah untuk memastikan generasi mendatang bisa memanfaatkannya dalam keadaan sebaik dan seasli yang tersedia di masa kini. Dengan berkembangnya teknologi yang mampu mendeteksi tingkat keragaman genetik dan informasi sifat serta manfaat di dalamnya, ada kemampuan untuk melakukan konservasi di luar habitat (ex situ). Konservasi ex situ dilakukan untuk tujuan pemulihan kondisi spesies di habitat alamnya. ${ }^{121}$ Konservasi ex situ SDG laut, selain untuk tujuan pemulihan juga dibutuhkan untuk pemanfaatan secara optimal tanpa harus terus menerus melakukan penelitian ke situs atau merusak keanekaragaman hayati di alam. Oleh karenanya pelindungan SDG laut melalui konservasi eks situ sama pentingnya dengan konservasi in situ.

\section{5.a. Konservasi In situ}

Konservasi in situ dilakukan berbasis pada kawasan lindung (protected area). ${ }^{122}$ Penjelasan ilmiah dari kebutuhan konservasi in situ atas SDG adalah bahwa

118 Ibid, Pasal 194. Lihat juga Pasal 196 ayat (1) UNCLOS: Berkenaan dengan kegiatan yang menggunakan teknologi di laut termasuk di dalamnya penelitian ilmiah kelautan, semua negara wajib mengambil tindakan yang diperlukan untuk mencegah, mengurangi dan mengendalikan polusi, introduksi spesies, benda asing atau baru yang bisa menyebabkan perubahan signifikan dan membahayakan/merusak di wilayah yurisdiksi/berada di bawah kendalinya.

119 Menurut J. Berthaud, pengelolaan SDG tidak lepas dari tiga standar kegiatan yang dilakukan secara linear yaitu pemanfaatan, evaluasi dan konservasi. Lihat: J. Berthaud, "Strategies for conservation of genetic resources in relation with their utilization," (Kluwer Academic Publishers, Netherlands, 1997).

120 Preambule Protokol Nagoya: "Recognizing that public awareness of the economic value of ecosystems and biodiversity and the fair and equitable sharing of this economic value with the custodians of biodiversity are key incentives for the conservation of biological diversity and the sustainable use of its components." UNCBD, Nagoya Protocol on Access to Genetic Resources and the Fair and Equitable Sharing of Benefits Arising from Their Utilization to the Convention on Biological Diversity, Nagoya 29 October 2010.

121 Pasal 9 huruf (c) CBD.

122 Pasal 8 huruf (a) CBD. 
pelindungan atau preservasi ${ }^{123}$ keanekaragaman SDG hanya bisa dilakukan selaras dengan pelindungan atau preservasi ekosistem dan spesies. Sebaliknya, pelindungan atau preservasi keanekaragaman SDG ditujukan utamanya untuk pemulihan ekosistem dan spesies.

Pengaturan tentang konservasi in situ untuk SDA hayati laut selain diatur dalam UU 31/2004 dan UU 32/2014, juga diatur dalam Undang-Undang Nomor 5 Tahun 1990 tentang Konservasi Sumber Daya Alam Hayati dan Ekosistemnya (UU 5/1990) ${ }^{124}$ dan Undang-Undang Nomor 27 Tahun 2007 tentang Pengelolaan Wilayah Pesisir dan Pulau-Pulau Kecil (UU 27/2007). ${ }^{125}$ Dengan adanya pengaturan tentang hal yang sama dalam keempat UU tersebut, seyogianya kegiatan konservasi dilakukan berkesinambungan. Namun yang terjadi adalah adanya irisan kewenangan antara kementerian bidang kelautan dan perikanan $(\mathrm{KKP})^{126}$ dengan kementerian bidang pelindungan SDA hayati $(\mathrm{KLHK})^{127}$, maupun pemerintah daerah. ${ }^{128}$ Irisan kewenangan terutama terlihat dalam hal pelindungan spesies dan SDG laut berupa biota bergerak. ${ }^{129}$ Tidak jarang hal ini menjadi penghambat efektivitas upaya konservasi.

123 Preservasi merupakan serapan dari istilah dalam bahasa Inggris: preservation. Dalam Kamus Besar Bahasa Indonesia, preservasi diartikan sebagai: pengawetan; pemeliharaan; penjagaan; perlindungan.

124 Indonesia (i), Undang-Undang tentang Konservasi Sumber Daya Alam Hayati dan Ekosistemnya, UU No. 5 Tahun 1990, LN Tahun 1990 No. 49.

125 Indonesia (j), Undang-Undang tentang Pengelolaan Wilayah Pesisir dan Pulau-Pulau Kecil, UU No. 27 Tahun 2007, LN Tahun 2007 No. 84, TLN No. 4739.

126 Saat ini merupakan kewenangan Kementerian Kelautan dan Perikanan.

127 Saat ini merupakan kewenangan Kementerian Lingkungan Hidup dan Kehutanan (sebelumnya merupakan kewenangan Kementerian Kehutanan).

128 Sampai akhir tahun 2013, KKP telah mencadangkan Taman Nasional Perairan seluas 3.521.130,01 Ha dan memfasilitasi pencadangan Kawasan Konservasi Perairan Daerah (KKPD) seluas 5.561.463,09 Ha. KKP juga telah menetapkan 8 kawasan konservasi yang diserahterimakan dari Kementerian Kehutanan (sekarang KLHK) dengan total luas 723.984,00 Ha. Kawasan Konservasi laut yang diinisiasi dan pengelolaannya berada di bawah wewenanga KLHK seluas 4.694.947,55 Ha. Sehingga keseluruhan luas kawasan konservasi perairan di Indonesia adalah 15.764.210,85 Ha. Lihat: KKP, “Informasi Kawasan Konservasi Perairan Indonesia", (Direktorat Konservasi Kawasan dan Jenis Ikan, Direktorat Jenderal Kelautan, Pesisir, dan Pulau-pulau Kecil, Kementerian Kelautan, 2013), hlm. 2.

129 Irisan kewenangan konservasi SDA hayati laut berpotensi menimbulkan konflik kewenangan. Pada konservasi di tingkat jenis dan genetik, konflik sangat mungkin timbul. Pemicu konflik diantaranya: (1) Adanya perbedaan daftar status pelindungan spesies maupun jenis spesies yang dilindungi antara KKP dengan KLHK (Bandingkan: PP No. 7 Tahun 1999 tentang Pengawetan Jenis Tumbuhan dan Satwa dengan Permen KP No. PER.03/MEN/2010 tentang Tata Cara Penetapan Status Perlindungan Jenis); (2) Pembedaan kewenangan pengelolaan konservasi kawasan berpotensi menyebabkan beberapa kawasan yang mempunyai nilai konservasi tinggi namun belum ditetapkan menjadi tidak berpengelola. [Diolah oleh penulis]. 
Penyebab terjadinya irisan kewenangan diantaranya: (1) UU 5/1990 bermaksud mengatur konservasi baik di daratan maupun perairan (termasuk laut) akan tetap UU 31/2004 dan UU 27/2007 mengatur kembali sebagai lex specialis untuk konservasi di wilayah laut serta pesisir dan pulau-pulau kecil. Pengaturan lebih khusus ini tidak disertai mandat tegas tentang pembagian atau pengalihan kewenangan yang semula ada pada KLHK ke KKP. (2) UU 31/2004 dan UU 27/2007 memberikan kewenangan pengelolaan kawasan konservasi tidak hanya bagi pemerintah pusat yaitu KKP tetapi juga kepada pemerintah daerah. Sementara UU 5/1990 dan turunannya hanya memberikan kewenangan bagi KLHK.

Adapun UU yang secara jelas menyebutkan adanya konservasi sampai tingkat genetik adalah UU 31/2004: “Dalam rangka pengelolaan sumber daya ikan, dilakukan upaya konservasi ekosistem, konservasi jenis ikan, dan konservasi genetika ikan." 130 Pengaturan tentang konservasi ini kemudian dijabarkan dalam pengaturan yang lebih teknis yaitu Peraturan Pemerintah Nomor 60 tahun 2007 tentang Konservasi Sumber Daya Ikan (PP 60/2007) ${ }^{131}$. PP 60/2007 mengatur konservasi di tingkat ekosistem, jenis, sampai genetik serta kawasan konservasi perairan ${ }^{132}$. Sayangnya, pengaturan tentang konservasi genetik belum cukup jelas diatur. Pasal 29 ayat (1) PP 60/2007 hanya menyatakan bahwa konservasi sumber daya genetik ikan dilakukan melalui upaya pemeliharaan, pengembangbiakan, penelitian dan pelestarian gamet. Untuk upaya pemeliharaan, pengembangbiakan dan penelitian untuk konservasi genetik diberlakukan mutatis mutandis ketentuan mengenai konservasi jenis/spesies. ${ }^{133}$

Meskipun PP 60/2007 tidak secara eksplisit menyinambungkan konservasi ekosistem dan spesies dengan konservasi SDG laut, upaya konservasi SDG laut secara in situ dapat diwadahi dengan menjalankan aturan tentang konservasi

130 Pasal 13 ayat (1), UU 31/2004.

131 Pemerintah RI, Peraturan Pemerintah tentang Konservasi Sumber Daya Ikan, PP No. 60 Tahun 2007, LN No. 134, TLN No. 4779. Perlu dipahami bahwa yang dimaksud dengan sumber daya ikan menurut UU 31/2004 dan turunannya adalah potensi semua jenis organisme yang seluruh atau sebagian dari siklus hidupnya berada di dalam lingkungan perairan. Artinya mencakup semua organisme hidup yang ada dan/atau hidup di laut.

132 Pasal 1 angka 8 PP 60/2007: “Konservasi Perairan adalah kawasan perairan yang dilindungi, dikelola dengan sistem zonasi, untuk mewujudkan pengelolaan sumber daya ikan dan lingkungannya secara berkelanjutan."

133 Pasal 29 ayat (2) PP 60 Tahun 2007. 
ekosistem $^{134}$ atau kawasan konservasi perairan ${ }^{135}$ dan jejaring kawasan konservasi perairan. ${ }^{136}$ Walaupun dalam penormaannya, pertimbangan SDG laut sebagai komponen yang perlu dilindungi di kawasan konsevasi perairan-pun tidak terlalu jelas. Objek SDG laut hanya disebutkan sebagai salah satu kriteria penetapan zona inti ${ }^{137}$ Akibatnya pejabat yang berwenang perlu menerjemahkan sendiri tentang cara melakukan konservasi SDG laut secara in situ.

\section{5.b. Konservasi Eks situ}

Konservasi SDG secara ex situ dapat dilakukan melalui konservasi terhadap spesies dan ekosistemnya atau konservasi terhadap material genetik menggunakan teknologi tertentu. Konservasi terhadap spesies dan ekosistem yang dimaksud merujuk pada konservasi di luar habitat alami spesies pada kawasan atau areal tertentu dengan mengintegrasikan kegiatan konservasi keanekaragaman genetik. Contohnya adalah kebun binatang dan kebun botani. Adapun konservasi material genetik menggunakan teknologi tertentu biasanya dilakukan dengan koleksi genetik melalui media laboratorium penyimpanan khusus. Contohnya adalah konservasi melalui media penyimpanan in vitro, media penyimpanan DNA, dan bank gen. ${ }^{138}$

134 Pasal 6 ayat (1) PP 60 Tahun 2007 mengatur bahwa konservasi ekosistem dilakukan melalui kegiatan perlindungan habitat dan populasi ikan, rehabilitasi habitat dan populasi ikan, penelitian dan pengembangan, pemanfaatan sumber daya ikan dan jasa lingkungna, pengembangan sosial ekonomi masyarakat, pengawasan dan pengendalian dan/atau monitoring dan evaluasi.

135 Kawasan konservasi perairan dapat berupa Taman Nasional Perairan, Suaka Alam Perairan, Taman Wisata Perairan, dan Suaka Perikanan. Namun demikian, tidak ada juga penjelasan atau pengaturan lebih lanjut tentang perbedaan perlakuan antara masing-masing jenis kawasan tersebut. Pasal 8 ayat (2) PP 60/2007.

136 Jejaring kawasan konservasi perairan adalah kerja sama pengelolaan dua atau lebih kawasan konservasi perairan secara sinergis yang memiliki keterkaitan biofisik (Pasal 1 angka 2). Jejaring kawasan konservasi perairan dibentuk berdasarkan keterkaitan biofisik antar kawasan konservasi perairan disertai dengan bukti ilmiah yang berada pada suatu hamparan ekoregion serta memiliki keterkaitan ekosistem (Pasal 2). Lihat: Menteri Kelautan dan Perikanan, Peraturan Menteri Kelautan dan Perikanan tentang Jejaring Kawasan Konservasi Perairan, Permen KP No. 13/Permen-KP/2014, BN Tahun 2014 No. 365.

137 Menurut PP No. 26 tahun 2008, peraturan zonasi adalah ketentuan yang mengatur tentang persyaratan pemanfaatan ruang dan ketentuan pengendaliannya dan disusun untuk setiap blok/zona peruntukan yang penetapan zonanya dalam rencana rinci tata ruang. Zonasi Kawasan Konservasi Perairan menurut Permen KP 30/MEN/2010 adalah suatu bentuk rekayasa teknik pemanfaatan ruang di kawasan konservasi perairan melalui penetapan batasbatas fungsional sesuai dengan potensi sumber daya dan daya dukung serta proses-proses ekologis yang berlangsung sebagai satu kesatuan Ekosistem. Pasal 10 huruf g Permen KP 30/MEN/2010 mengatur: : "Zona inti ditetapkan dengan kriteria....g. mempunyai ciri khas sebagai sumber plasma nutfah bagi Kawasan Konservasi Perairan." Lihat: Menteri Kelautan dan Perikanan, Peraturan Menteri Kelautan dan Perikanan tentang Rencana Pengelolaan dan Zonasi Kawasan Konservasi Perairan, Permen KP No. 30/MEN/2010.

138 FAO, 1998, p. 510. Glowka (c), hlm. 15. 
Pentingnya konservasi ex situ terutama untuk pemulihan keragaman genetik pada in situ dan preservasi material genetik yang mempunyai manfaat bagi ketahanan ekologi maupun kebutuhan hajat hidup manusia. CBD mengatur bahwa negara anggota harus melakukan tindakan pemulihan dan rehabilitasi spesies terancam punah dan melakukan pengaturan serta pengelolaan koleksi sumber daya hayati dari habitat alami untuk konservasi ex situ. ${ }^{139}$

Konservasi ex situ harus dipandang sebagai upaya komplementer dari konservasi in situ. ${ }^{140}$ Sehingga konservasi in situ wajib adanya, tidak bisa digantikan dengan konservasi ex situ. Penegasan ini penting karena berkembang pandangan bahwa konservasi yang harus lebih diutamakan adalah konservasi ex situ. ${ }^{141}$ Pandangan seperti ini harus dihindari karena bisa menegasikan esensi dari konservasi itu sendiri yaitu untuk preservasi kondisi bagi generasi mendatang.

Berdasarkan PP 60/2007, pengaturan tentang konservasi genetik ex situ terlihat dari perintah untuk melakukan pelestarian gamet. ${ }^{142}$ Pelestarian gamet diartikan sebagai pelestarian SDG dengan cara menyimpan sel pembiakan berupa sel jantan (sperma) atau sel betina (ovum) yang dapat dilakukan dalam kondisi beku (bank sperma). ${ }^{143}$ Penjelasan ini memberikan batasan yang tidak perlu mengingat perkembangan teknologi pelestarian SDG ex situ sangat pesat sehingga bisa saja kebutuhan konservasi ex situ tidak sebatas pelestarian gamet. Di samping itu, PP ini tidak memberikan petunjuk tentang media yang digunakan untuk melakukan konservasi ex situ pelestarian gamet.

Pada praktiknya, konservasi ex situ yang sudah ada sebagian besar dilakukan untuk spesies panen serta spesies tumbuhan dan satwa terdomestikasi. ${ }^{144}$ Hal ini karena kepentingan konservasi spesies terdomestikasi lebih dekat pada pemanfaatan, baik pangan, pertanian, maupun kesehatan. Sementara pelindungan spesies liar masih belum menjadi fokus. Penelitian-penelitian ilmiah terhadap genetik dari spesies liar yang tidak berorientasi pemanfaatan sampai saat ini belum dimonitor dengan sistem yang memadai.

Sejak diundangkannya UU 32/2014, mandat untuk membangun sistem informasi dan data kelautan telah ada. Salah satu kategori sistem informasi dan

139 Pasal 9 huruf (c) dan (d) CBD.

140 Glowka (b), op. cit., hlm. 51.

141 Ibid, hlm. 52.

142 Pasal 29 ayat (1), PP 60/2007.

143 Penjelasan pasal 29 ayat (3), PP 60/2007.

144 Glowka (b), op. cit., hlm 52. 
data kelautan dalam UU 32/2014 adalah pengelolaan sumber daya kelautan, konservasi perairan dan pengembangan teknologi kelautan. ${ }^{145}$ Mandat ini seharusnya dimanfaatkan untuk membangun sistem basis data yang mutakhir untuk melakukan pengawasan terhadap kegiatan yang melibatkan SDG laut, untuk menjadi bahan pertimbangan kebijakan dan pelaksanaan konservasi. Sistem basis data juga menjadi prasyarat bagi konservasi ex situ. Paling tidak sistem ini membantu pemerintah mengontrol dengan baik informasi tentang kondisi SDG laut, jika modal pendanaan dan teknologi untuk membangun media konservasi ex situ SDG laut belum mendukung.

\section{Kesimpulan}

Kebutuhan akan pelestarian SDG laut menjadi salah satu prasyarat dalam mewujudkan pembangunan berkelanjutan serta mengejawantahkan komitmen Indonesia di tingkat internasional terutama melalui UNCLOS dan CBD. Namun di sana sini masih terdapat kekosongan hukum, di samping terdapat peraturan perundang-undangan yang belum berkelindan dan fungsi kelembagaan yang belum cukup koordinatif untuk mendukung upaya pelestarian SDG yang sesuai dengan agenda pembangunan berkelanjutan.

Aspek hukum pertama yang penting untuk dicermati adalah penerjemahan tentang penguasaan negara atas SDG laut dalam kewenangan pemerintah. Hal ini menjadi prasyarat sekaligus landasan untuk menyusun kerangka pengaturan lebih lanjut terkait pelestarian SDG laut sekaligus mempertegas sejauh mana masyarakat berhak atas keuntungan dari pemanfaatan SDG laut.

Pada pemanfaatan SDG laut, pengaturan terkait penelitian ilmiah kelautan atau bioprospecting yang sudah ada perlu diharmonisasikan dan diperkuat. Batasan berupa hak masyarakat dan jaminan pelindungan lingkungan hidup dalam melakukan kegiatan pemanfaatan SDG laut perlu lebih dipertegas. Akan tetapi perlu juga diperhatikan bahwa peraturan yang dibuat atau diperbaiki tidak menjadi penghambat semangat penelitian dan pengembangan, terutama bagi peneliti domestik. Adapun pengaturan terkait ABS harus dipastikan melahirkan mekanisme yang transparan dan akuntabel, di samping diarahkan untuk memberikan manfaat sebesar-besarnya bagi masyarakat Indonesia.

145 Pasal 40 ayat (2) UU 32/2014. 
Pada pelindungan SDG laut, perlu ada penyelarasan antara tumpang tindih kewenangan penyelenggaraan konservasi in situ. Pengaturan yang sudah ada juga perlu diperkuat untuk mendukung konservasi ex situ yang mutakhir dan ditujukan terutama untuk pemulihan keadaan lingkungan hidup dan ketahanan kesehatan dan pangan. Sistem basis data yang memuat inventarisir kekayaan laut penting dimiliki pemerintah untuk membantu optimalisasi pelaksanaan konservasi.

Secara singkat, kebutuhan dan tantangan dalam pelestarian SDG laut terletak pada perlunya kerangka kebijakan integratif yang mengakomodir penerjemahan penguasaan negara dan hak masyarakat atas pemanfaatan SDG laut, penguatan koordinasi antar instansi yang mengemban fungsi terkait pelestarian SDG laut dan kejelasan tentang pembagian kewenangan, serta penguatan dan harmonisasi pengaturan tentang penelitian ilmiah kelautan atau bioprospecting, mekanisme ABS, dan konservasi SDG laut baik in situ maupun ex situ. 


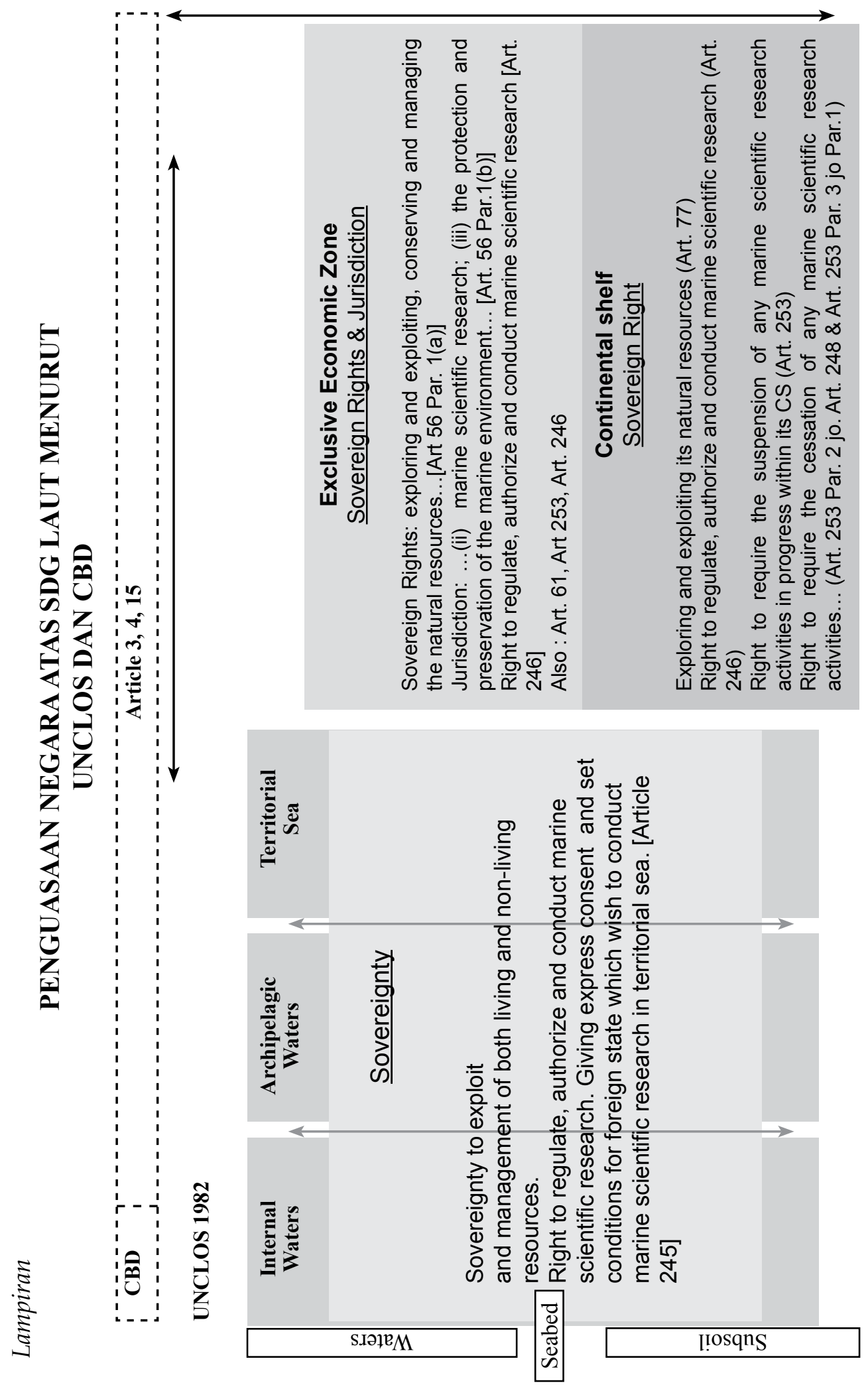




\section{Daftar Pustaka}

\section{Peraturan}

Indonesia. Undang-Undang Dasar Negara Republik Indonesia Tahun 1945. . Undang-Undang tentang Kelautan. UU No. 32 Tahun 2014. LN 2014 No. 294. TLN No. 5603. . Undang-Undang tentang Pengesahan United Nations Convention on the Law of the Sea, UU No. 17 Tahun 1985. (Konvensi Perserikatan Bangsa-Bangsa tentang Hukum Laut 1982).

- Undang-Undang tentang Sistem Nasional Penelitian, Pengembangan, dan Penerapan Ilmu Pengetahuan dan Teknologi. UU No. 18 Tahun 2002. LN 2002 No. 84. TLN No. 4219. . Undang-Undang tentang Pengesahan United Nations Convention on Biological Diversity (Konvensi Perserikatan Bangsa-Bangsa Mengenai Keanekaragaman Hayati). UU No. 5 Tahun 1994. . Undang-Undang tentang Perairan Indonesia. UU No. 6 Tahun 1996, LN Tahun 1996 No. 73. . Undang-Undang tentang Perubahan atas Undang-Undang Nomor 31 Tahun 2004 tentang Perikanan. UU No. 45 Tahun 2009. LN 2009 Nomor 154. . Undang-Undang tentang Zona Ekonomi Eksklusif Indonesia. UU No. 5 Tahun 1983.

Menteri Kelautan dan Perikanan RI, Peraturan Menteri Kelautan dan Perikanan tentang Tata Cara Pemanfaatan Jenis Ikan dan Genetik Ikan. Permen KKP No. Per.04/ MEN/2010

Menteri Kelautan dan Perikanan RI. Peraturan Menteri Kelautan dan Perikanan tentang Organisasi dan Tata Kerja Kementerian Kelautan dan Perikanan., Permen KKP No. 23/PERMEN-KP/2015.

Pemerintah RI. Peraturan Pemerintah tentang Konservasi Sumber Daya Ikan. PP No. 60 Tahun 2007. LN No. 134. TLN No. 4779. PP 60/2007. 


\section{Perjanjian Internasional}

Convention on Biological Diversity Conference. Nagoya Protocol on Access to Genetic Resources and the Fair and Equitable Sharing of Benefits Arising from Their Utilization to the Convention on Biological Diversity. Diadopsi pada 29 Oktober 2010.

United Nations. Convention on Biological Diversity. Rio de Jeneiro, 5 June 1992.

United Nations. United Nations Convention on the Law of the Sea. Montego Bay, 10 December 1982 (UNCLOS 1982).

\section{Buku, Artikel dan Jurnal}

Ayu, Miranda Risang, Harry Alexander dan Wina Puspitasari. Hukum Sumber Daya Genetik, Pengetahuan Tradisional dan Ekspresi Budaya Tradisional di Indonesia. PT Alumni: Bandung, 2014.

Berthaud, J. "Strategies for conservation of genetic resources in relation with their utilization." Kluwer Academic Publishers, Netherlands, 1997.

Brown, Anthony H.D. Indicators of Genetic Diversity, Genetic Erosion and Genetic Vulnerability for Plant Genetic Resources for Food and Agriculture. Rome, 2008.

Correa, Carlos M. "Sovereign and Property Rights over Plant Genetic Resources." disampaikan dalam FAO background study paper No. 2. Commission on Plant Genetic Resources, First Extraordinary Session. Roma, 7-11 November 1994.

FAO. Coping with climate change - the roles of genetic resources for food and agriculture. Rome, 2015.

Fatimah, Isna. "Hak Berdaulat atas Sumber Daya Genetik Tanaman untuk Pangan dan Pertanian." Skripsi: Fakultas Hukum Universitas Indonesia, 2013.

Glowka, Lyle. "Genetic resources, marine scientific research and the international seabed Area." Vol 8 Issue 1 1999. Blackwell Publishers, Ltd: Oxford, 1999.

. "the Deepest of Ironies: Genetic Resources, Marine Scientific Research, and the Area." The University of Chicago, 1996.

. Et. al. A Guide to the Convention on Biological Diversity. International Union for Conservation of Nature and Natual Law (IUCN), 1996. 
Greiber, Thomas. "Access and Benefit Sharing in Relation to Marine Genetic Resources from Areas Beyond National Jurisdiction: A Possible Way Forward." Bonn: BN Federal Agency for Nature Conservation, 2011.

Et. al.. An Explanatory Guide to the Nagoya Protocol on Access and BenefitSharing. IUCN: Gland, Switzerland, 2012.

Gudmundsson, Eyjolfur. "Challenges of Marine Biodiversity." Chicago: The University of Chicago Press, 1998.

IUCN, World Conservation Strategy, IUCN-UNEP-WWF, 1980.

Kuehn, Robert R. “A Taxonomy of Environmental Justice.” Environmental Law Reporter Vol.30 p. 10681, 2000. Diakses dari Social Science Research Network: http:/ / papers. ssrn.com/sol3/papers.cfm?abstract_id=628088 pada 5 Oktober 2015.

Kusumaatmadja, Mochtar dan Etty R. Agoes. Pengantar Hukum Internasiona., Ed. 2. Alumni, Bandung, 2003.

Leary, David Kenneth. International Law and the Genetic Resources of the Deep Sea. Koninklijke Brill NV, Leiden, The Netherlands, 2007.

Lembaga Ilmu Pengetahuan Indonesia. Kekinian Keanekaragaman Hayati Indonesia 2014. Pusat Penelitian Biologi LIPI: Jakarta, 2014.

Lubis, Efridani. “Penerapan Konsep Sovereign Right dan Hak Kekayaan Intelektual dalam Perspektif Perlindungan dan Pemanfaatan SDG Indonesia." Disertasi: Universitas Indonesia, 2009.

Parthiana, I Wayan. Landas Kontinen dalam Hukum Laut Internasional. Bandung: CV Mandar Maju, 2005.

Patricia, Annie Kameri-Mbote, Philippe Cullet. “The Management of Genetic Resources: Developments In The 1997 Sessions of the Commission On Genetic Resources For Food and Agriculture." Colorado Journal of International Environmental Law and Policy, 1997.

Proelss, Alexander. "ABS in Relation to Marine GRs" dalam Winter, Gerd dan Evanson Chenge Kamau. Genetic Resources, Traditional Knowledge and the Law: Solutions for Access and Benefit Sharing. London: Earthscan, 2009.

Salpin, S. Arico, C. Bioprospecting of Genetic Resources in the Deep Seabed: Scientific, Legal and Policy Aspects. United Nations University-Institute of Advanced Studies, 2005. 
Sands, Pilippe. Principles of International Environmental Law. $2^{\text {nd }}$ Ed. Cambridge University Press: New York, 2003,

Secretariat of the Convention on Biological Diversity. "Uses of Genetic Resources." UNCBS Factsheet, 2010.

Siswandi, Achmad Gusman Catur. "Marine Bioprospecting: International Law, Indonesia and Sustainable Development." Thesis submitted for the degree of Doctor of Philosophy of The Australian National University, January 2013.

Syatauw, J.J.G. "Some Newly Established Asian States and the Development of International Law." The Hague, 1961.

United Nations. "Marine Scientific Research: A revised guide to the implementation of the relevant provisions of the United Nations Convention on the Law of the Sea." New York: United Nations Division for Ocean Affairs and the Law of the Sea Office of Legal Affairs, 2010.

Warner, Robin. "International Standards for Protection of the Marine Environment." diakses dari http://www.isa.org.jm/files/documents/EN/Workshops/2011/ Presentations/8_ RWarner.pdf pada 3 Juni 2015.

Winter, Gerd dan Evanson Chenge Kamau. Genetic Resources, Traditional Knowledge and the Law: Solutions for Access and Benefit Sharing. London: Earthscan, 2009.

Zewers, Kirsten E. "Debated Heroes from the Deep Sea - Marine Genetic Resources." WIPO Magazine, April 2008. Diakses dari http://www.wipo.int/ wipo_magazine/ en/2008/02/article_0008.html pada 3 Juni 2015.

\section{Lainnya}

Arieta J.M., Arnaud-Haond, dan C.M. Duarte, “What Lies Underneath: conserving the Oceans' Genetic Resources." dalam presentasi berjudul “Marine Biodiversity and Gene Patents: Balancing the Preservation of Marine Genetic Resources (MGR) and the Equitable Generation of Benefits for Society." Mediterranean Institute for Advanced Studies [IMEDEA], Spanish National Research Council [CSIC], 2010.

Indonesian Center for Environmental Law dan Pusdiklat Teknis Peradilan Mahkamah Agung RI. "Materi Ajar Sertifikasi Hakim Lingkungan Hidup." ICEL, 2014. 
Interridge. http://www.interridge.org/irvents/ventfields_list_all?page=1 , diakses pada 26 September 2015.

Kementerian Kelautan dan Perikanan. "Informasi Kawasan Konservasi Perairan Indonesia." Direktorat Konservasi Kawasan dan Jenis Ikan, Direktorat Jenderal Kelautan, Pesisir, dan Pulau-pulau Kecil, Kementerian Kelautan, 2013.

Kementerian Lingkungan Hidup. "Deskripsi Peta Ekoregion Laut Indonesia." Deputi Tata Lingkungan, Kementerian Lingkungan Hidup, Jakarta, 2013.

United Nations. "The United Nations Convention on the Law of the Sea (A historical perspective)." Diakses dari www.un.org/Depts/los/convention_historical_ perspective.htm pada 5 Oktober 2015.

Zewers, Kirsten E. “Debated Heroes from the Deep Sea - Marine Genetic Resources," (WIPO Magazine, April 2008), diakses dari http://www.wipo.int/wipo magazine/en/2008/02/article_0008.html pada 3 Juni 2015. 